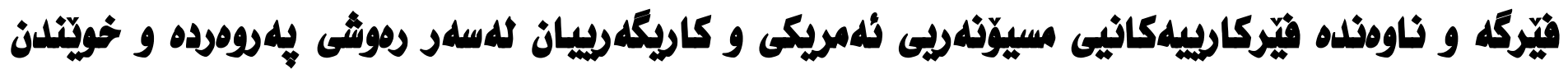

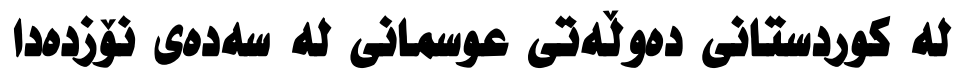

\section{سامان حسيّز ئه حملد}

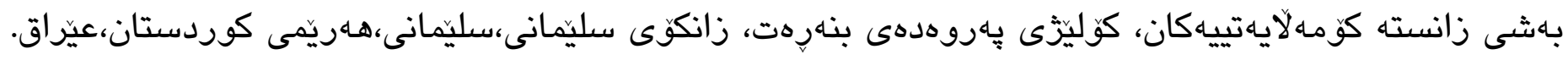
Saman.abdullah@univsul.edu.iq :يمـاهيلْ

يوخته:

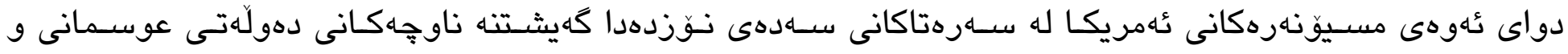

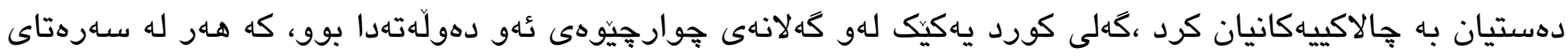

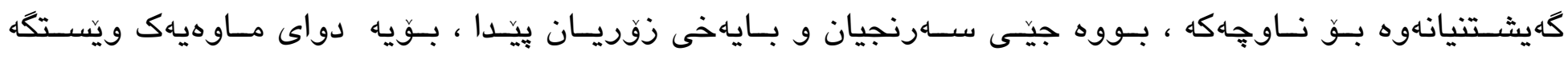
مسيوّنرييهكانى خوّيان له جهند شاريكى كوردستان كردهوه و دهستيان كرد به كارو جالاكيهكانيان له ناوجهـكهدا. وهك زانراوه، مسيوّنهريى ئهميكى بهشيكى زورى جالاكييهكانيان له بوارى روشنبيرى و خوينتدن و فيّربووندا بووه

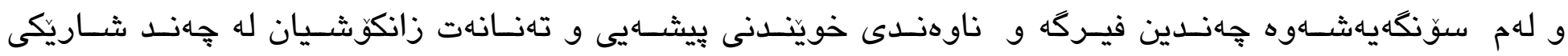

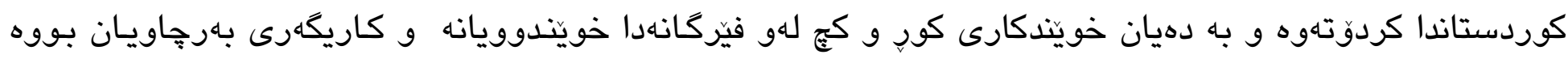

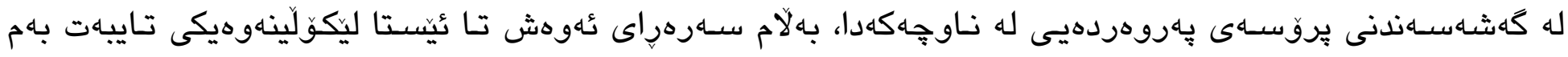

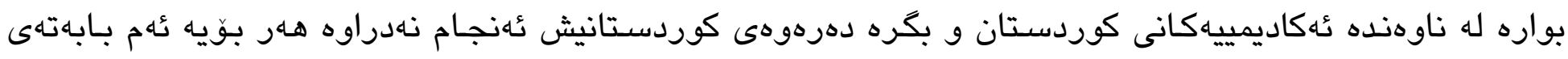

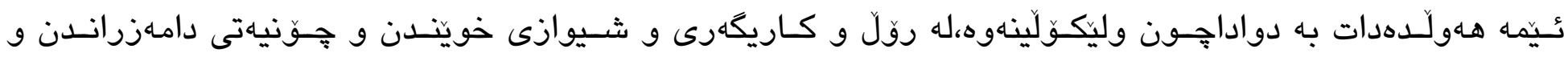

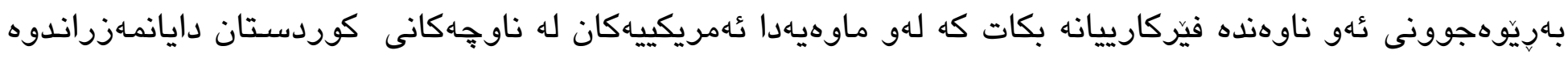

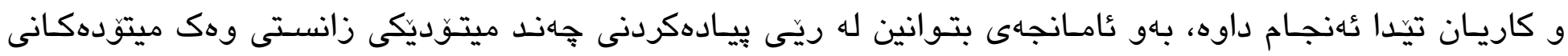
كيّرانهوه و بهراوردكارى و شيكارى تيشكيكى زانستيانه بخهينه سـه ئهم بابهته و له رهههنده جياجياكانى بكولينهوه. 
ئهم بابهته كه به ناونيشانى (فيّركه و ناوهنده فيّركارييهكانيى مسيوّنهريى ئهريكى و كاريكهرييان لهسهار رهوشى

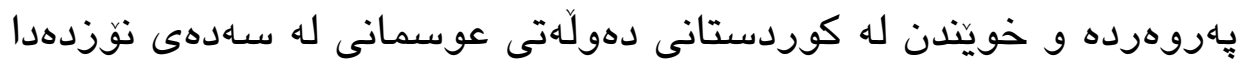

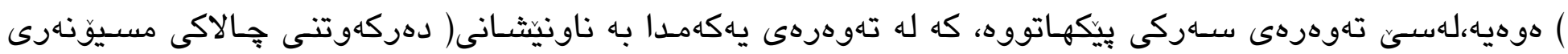

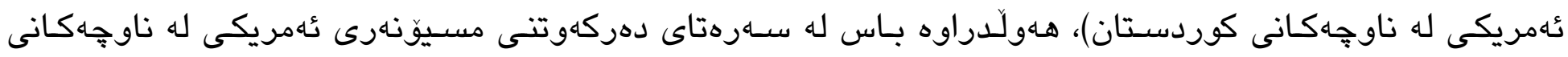

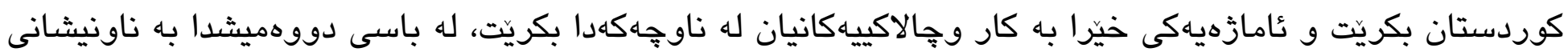

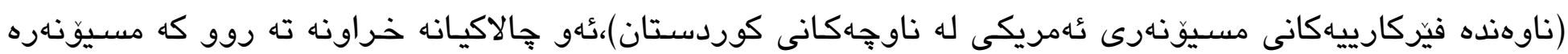

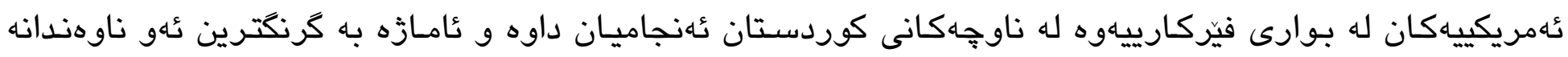

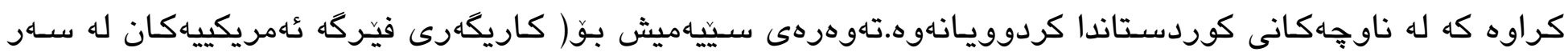

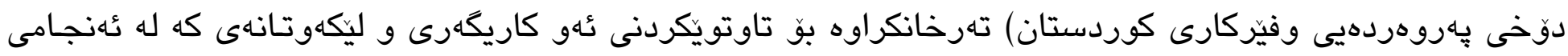

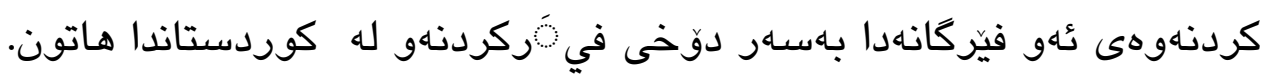

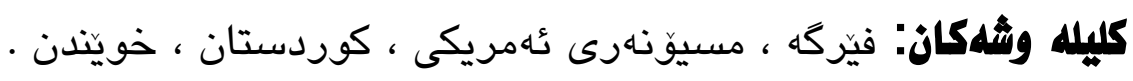

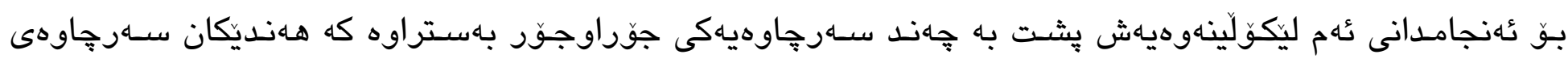

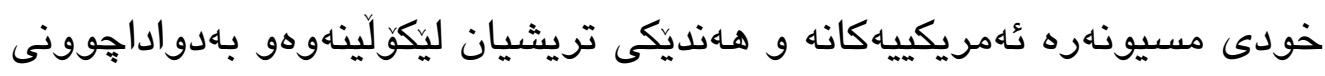

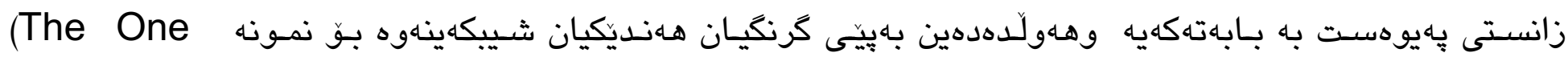
Hundredth Annual Report of the American Bord Commissioners for foreign missions) كه يهكيكه لهو كتيبانهى له سـالى · 191 هوه لهلايهن خودى بوّردى ئهمريكييهوه له شـارى بوّستن دهربـارهى كارو

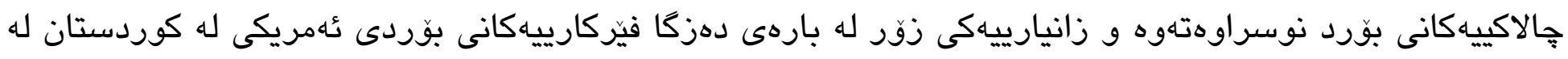

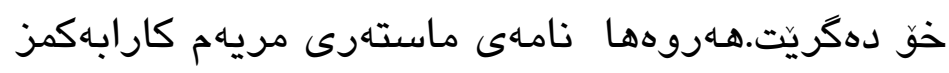

Karabekmez , Meryem,(2012), The Role of Provincial Directors of Education in the ( JFormation of Modern Ottoman Schooling ,1881-1908

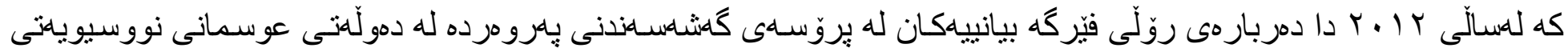

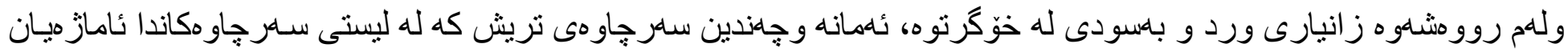
يِّيكر واوه. 


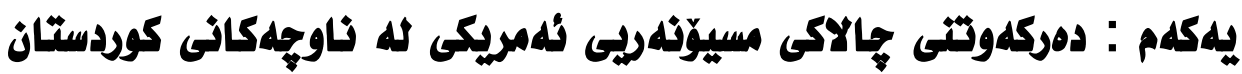

سهرهتاى كارى مسيوّنهرى له ئهريكا به كارهكانى ريكخراوهى بوّردى ئهريكى بوّ كومسيارى نيّرده دهرهكييهكان (American Board of Commissioners for Foreign Missions (ABCFM))

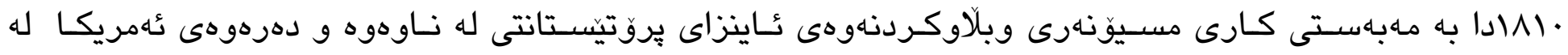

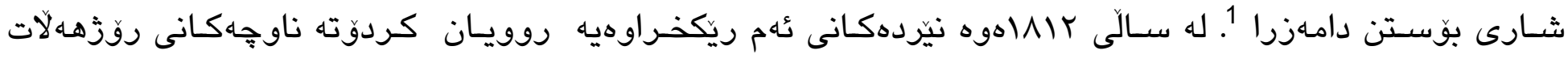

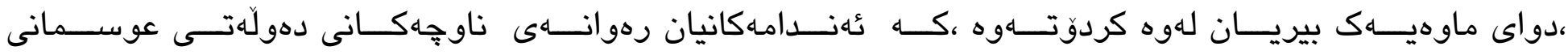

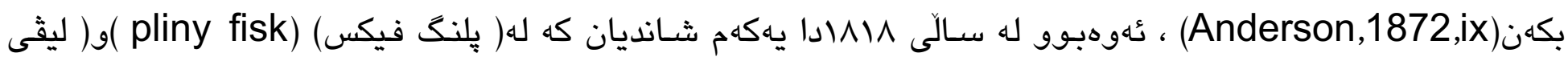

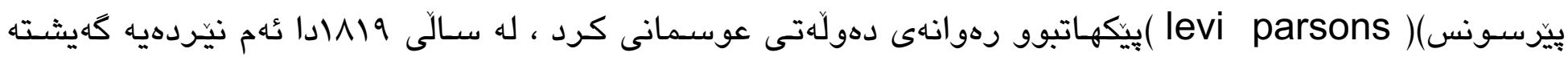

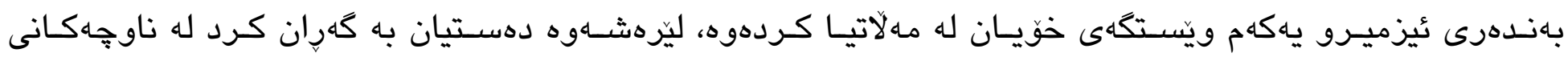

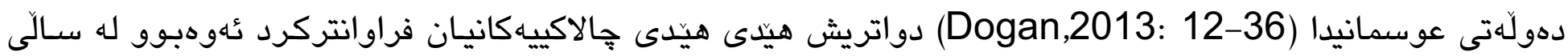

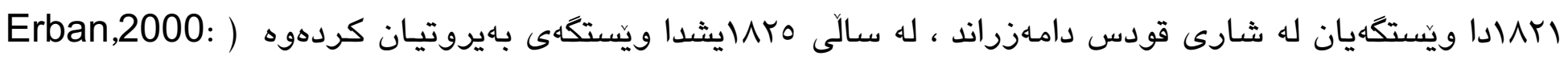

لـه سـالانى دواتردا ئهم ريكخراوه زياتر برهويان به كارهكانيان دا لـه ناوجهـكانى دهولَهتى عوسمانى ئهوهبوو له

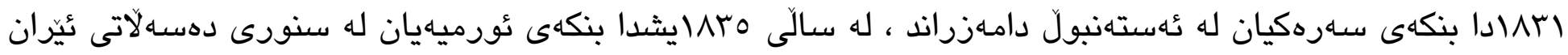
دامهزراند(Thomas,1853:220).

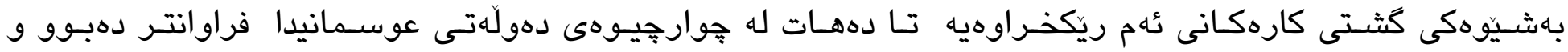

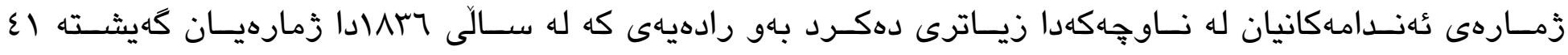

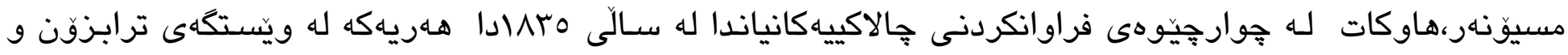

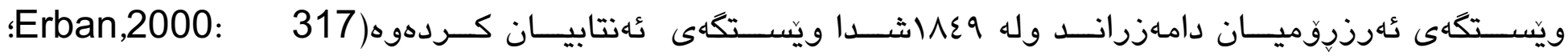
.(Kennedy,2008: 30

له نيوهى دووهمى سهدهى نوزدهدا و بهتايبهتيش دواى عٔهوهى له 1847 دا فـهرمانيكى سولتّانى دهرجهوو ودانى بـه

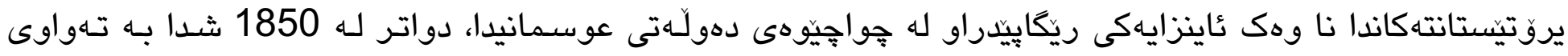

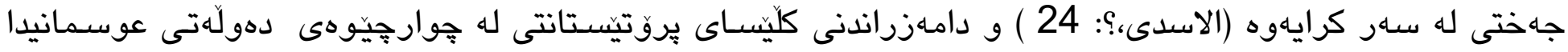

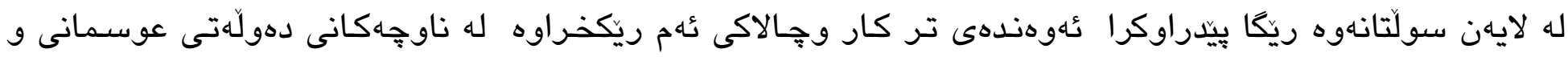




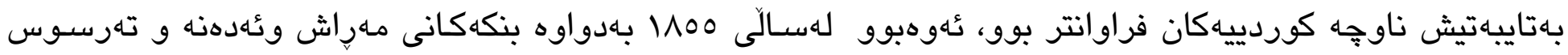

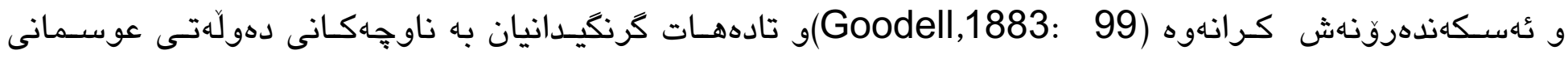

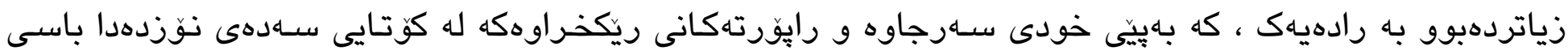

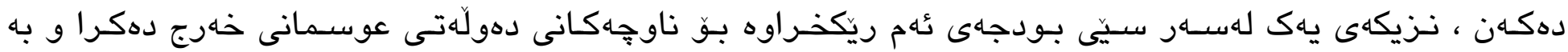

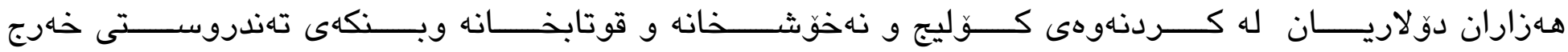

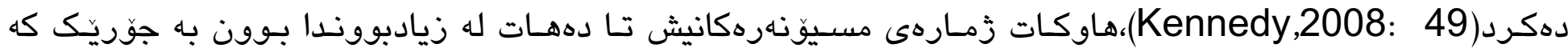

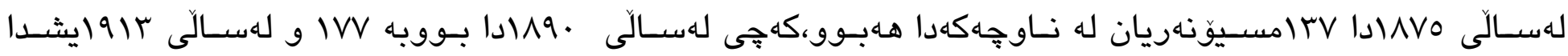

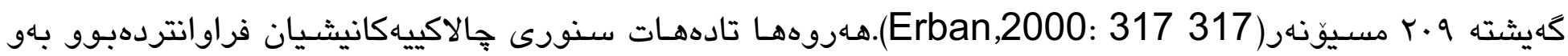

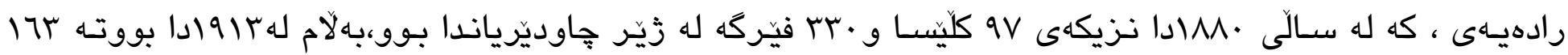

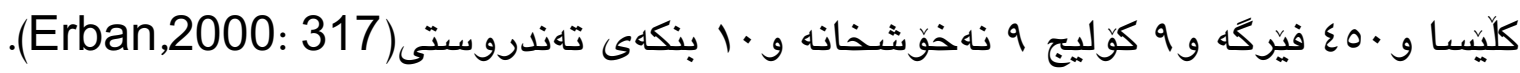

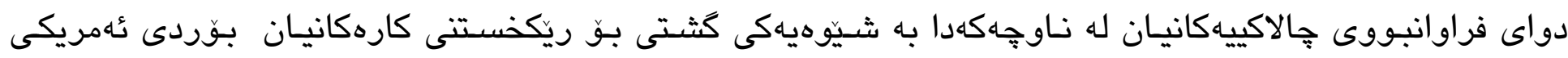

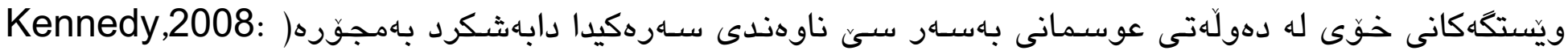
:(32-35

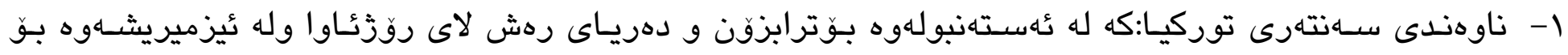

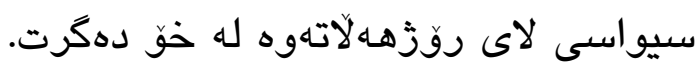

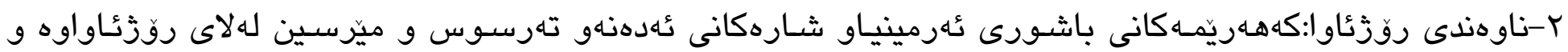

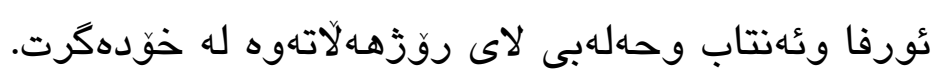

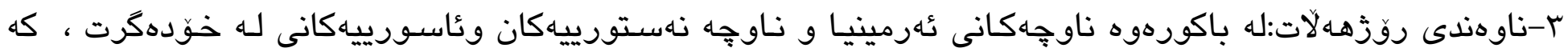

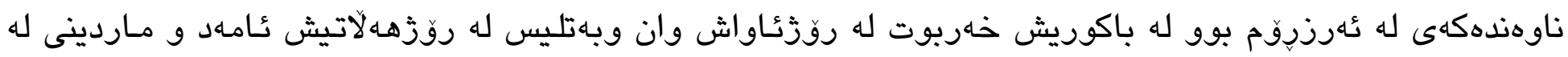
خوَدهكرت.

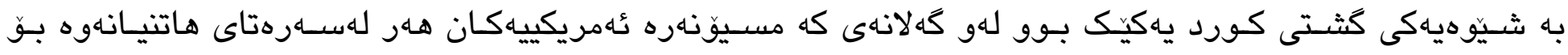

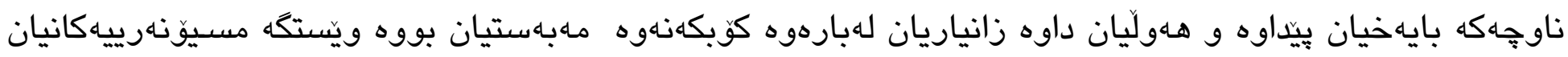

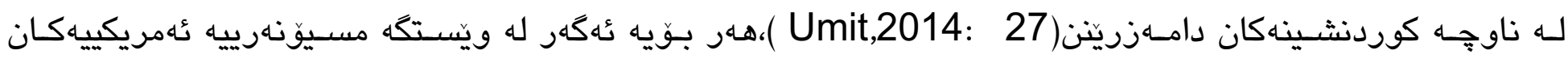

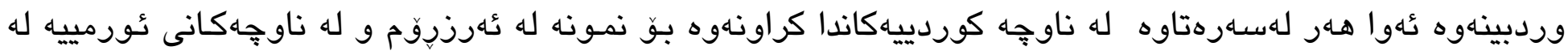


ئيّران ئهمه جكَه لهوهى كه ناوهندى روزّهالاتى بوّردى ئهمريكى وهك بينيمان تايبهت بوو به ناوجهكانى كوردستان و هـندينك ناوجهى كورديش له جِوارجيّوهى ناوهندكانى تردا بوون.

ناوهندى روذههلآت بهلاى ئهمريكيهكانهوه سـرهراى ئهوهى دزوارترين ناوهندى كاركردنيان بووه ئهويش به هوَى

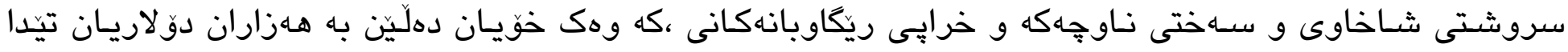

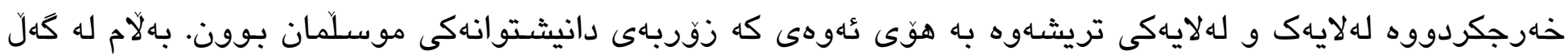

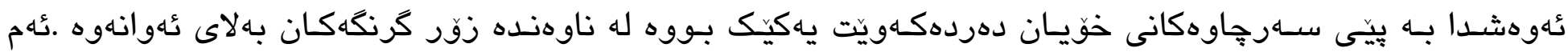

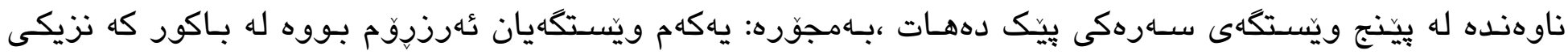
دهرياى رهش بووه ،له نزيك سنورى روسيا وجهندين بزيشك و زانا و مسيوّنهرى بانكخواز كاريـان تيّدا كردووه.

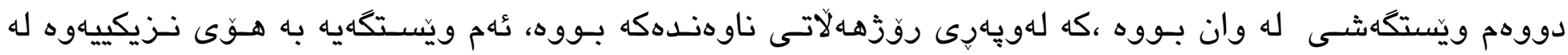

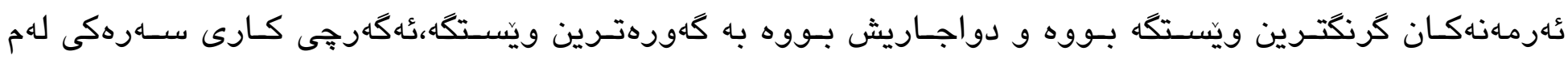

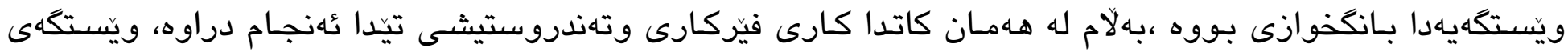
سيّيهميش له بهتليس بووه،وهك خويان كوتوويانه سهختترين ويستكهى كاركردنيان بووه وناوجهاهيهكى داخراو بووه

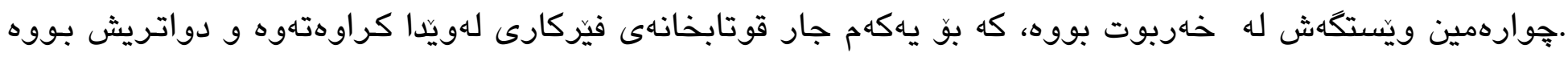

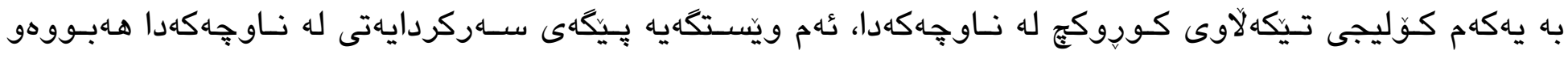

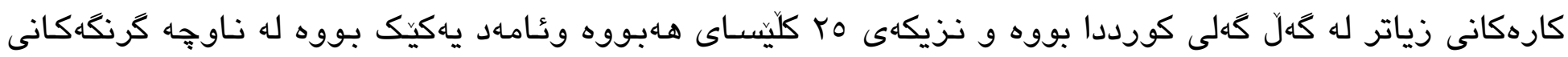

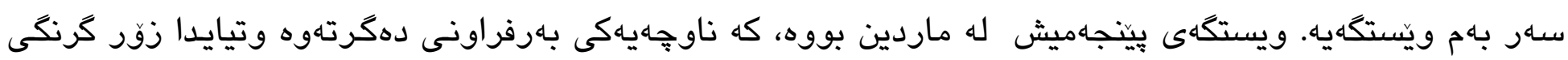

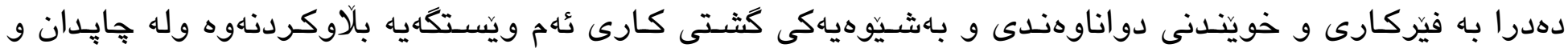

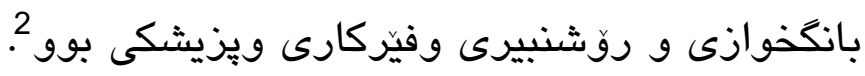

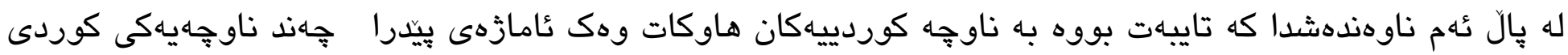

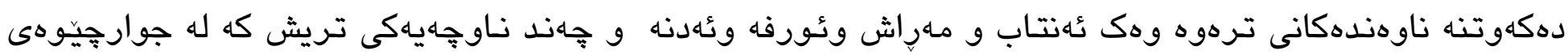

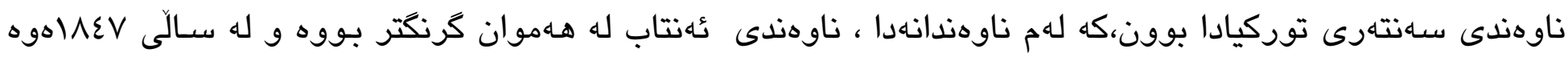

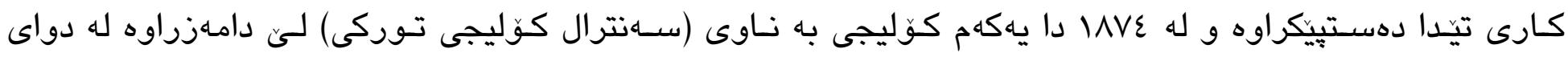

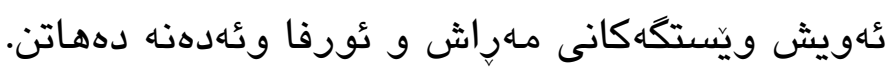

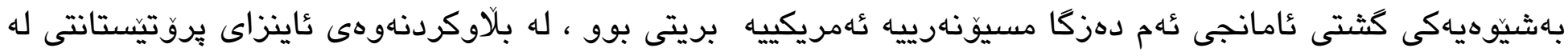

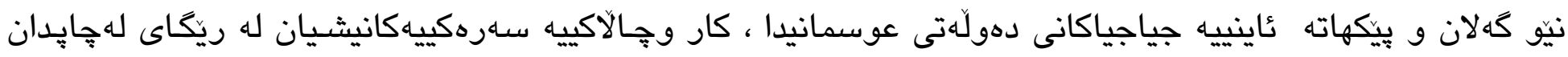

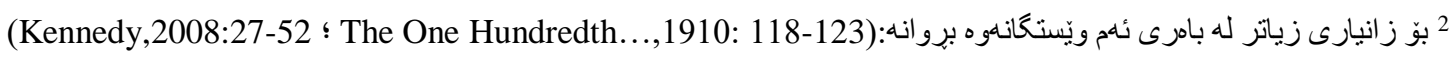




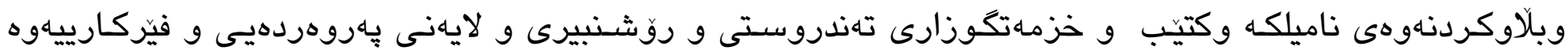

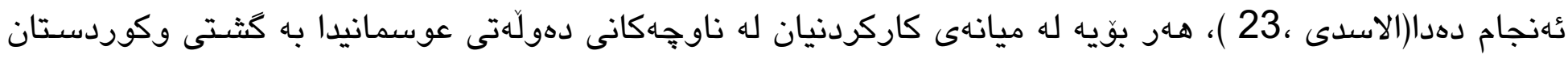

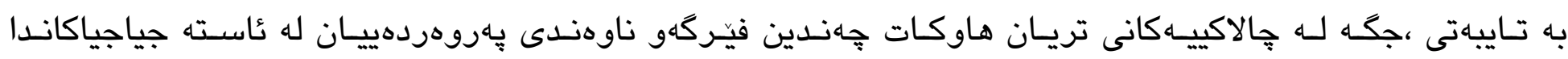

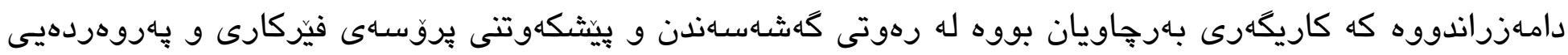

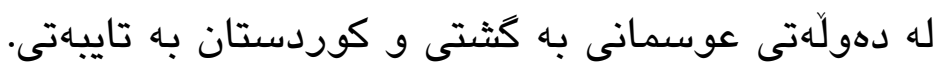

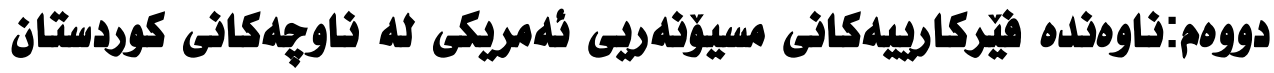

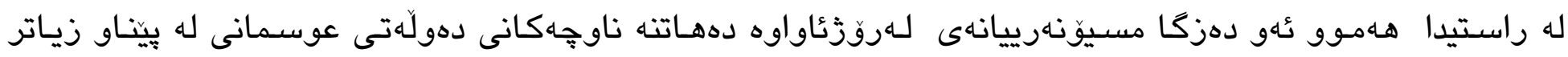

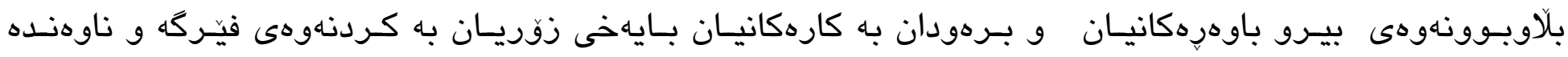

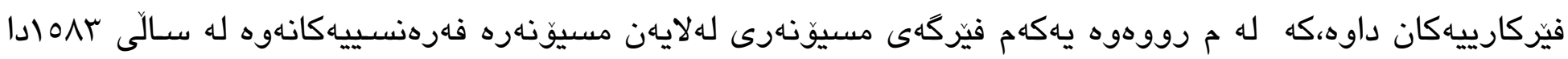

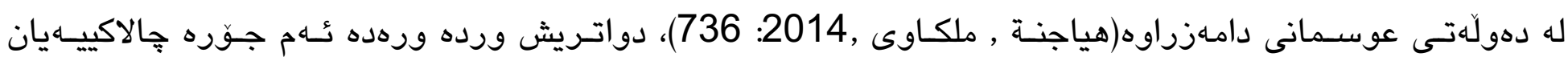

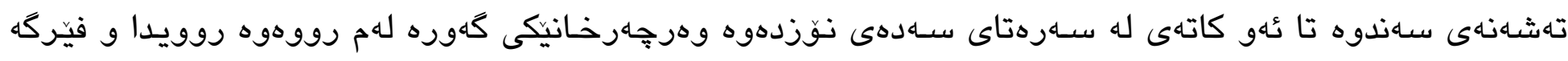

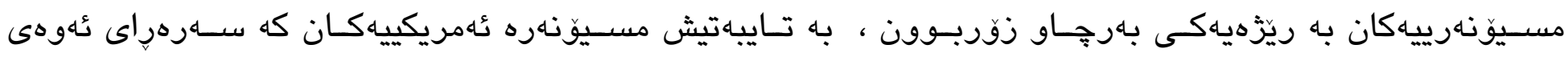

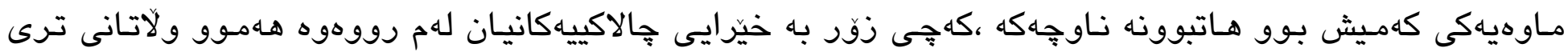

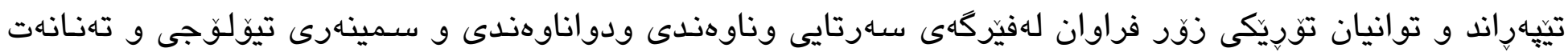

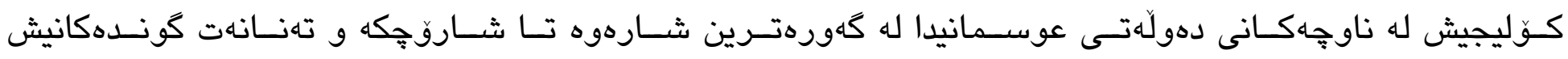
دامهزرينتن(Ozutuk and Ozgur,2013:

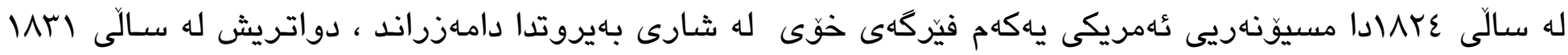

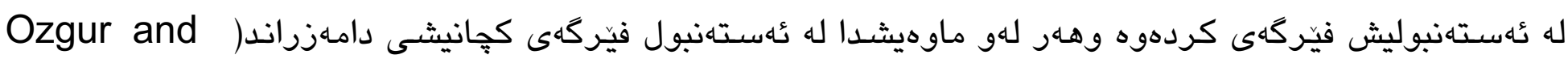
65 Muhammet,2015: 6

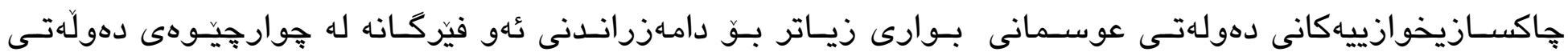

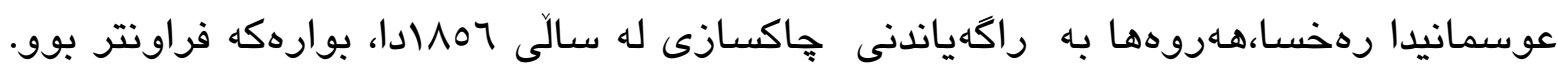

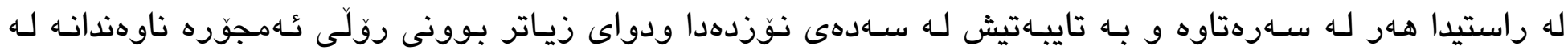

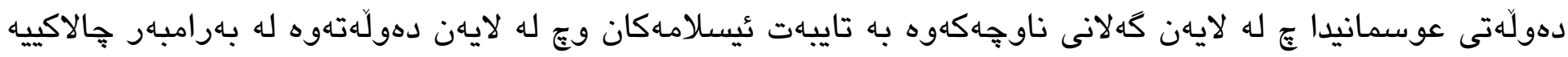

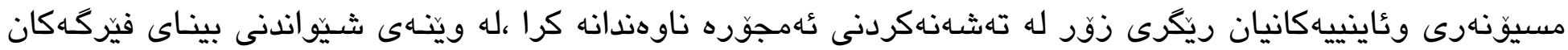




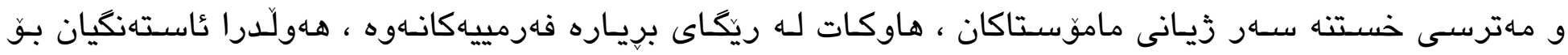

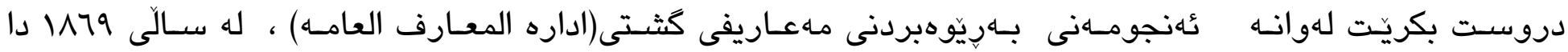
ياسايهكى بوّ دامهزراندنى ئهمجّره فيّركانه دهركرد كه تيايدا دوو مهرجى بوّ دانابوون ئهوانيش يهكهم بيّويسته يِيش

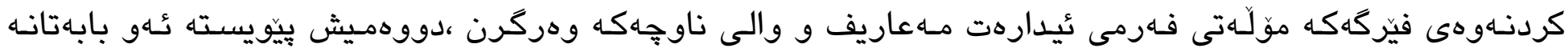

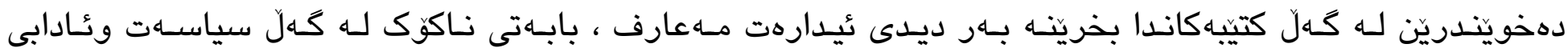

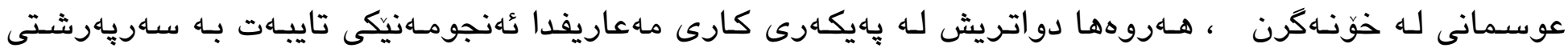

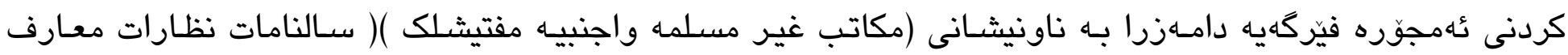

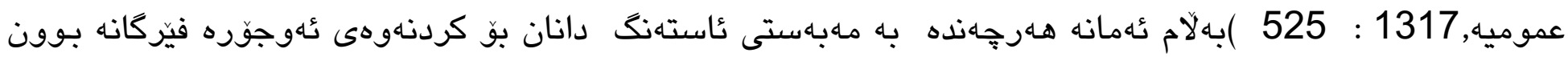

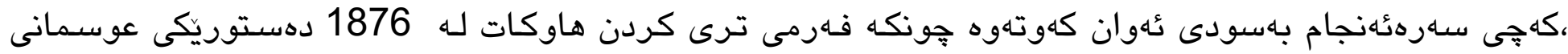

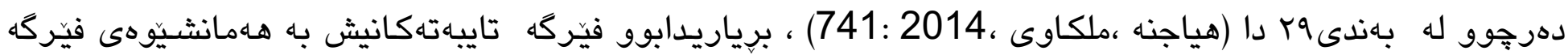

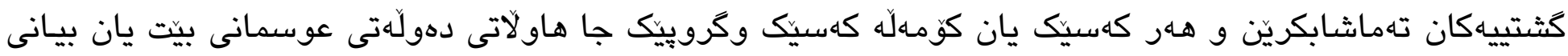

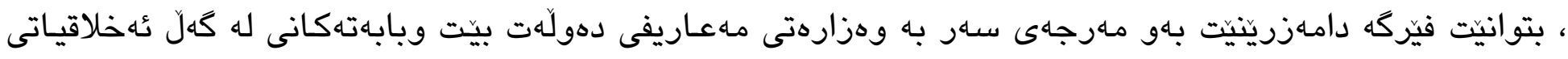

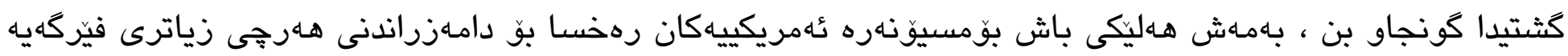

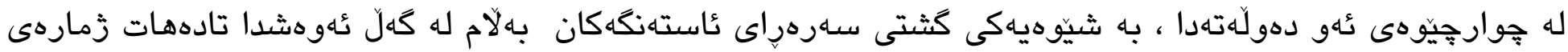

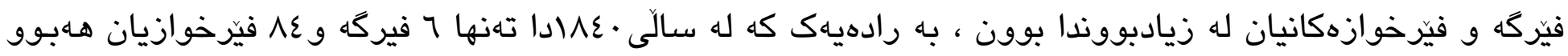

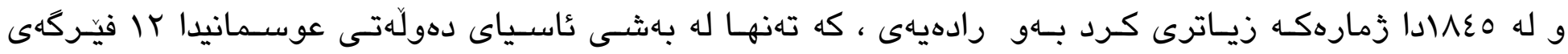

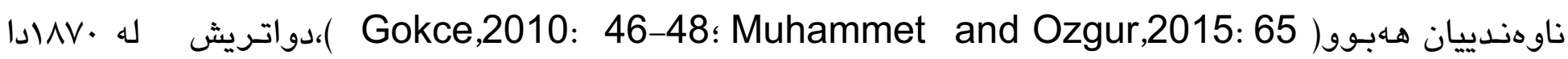

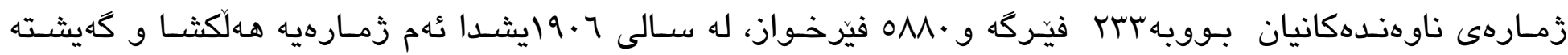

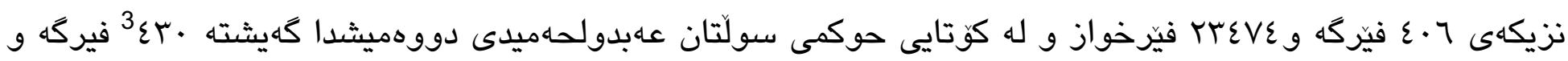

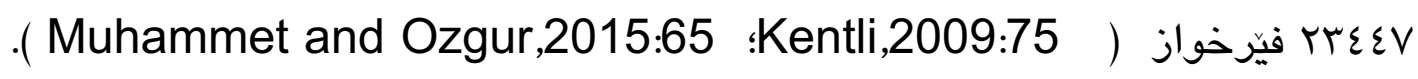

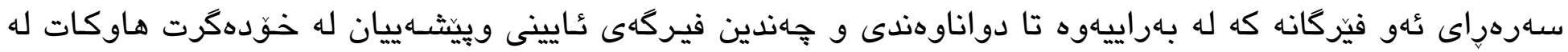

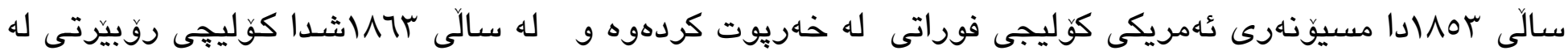

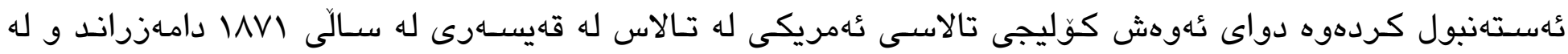

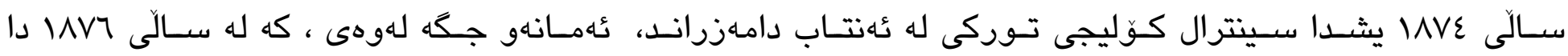

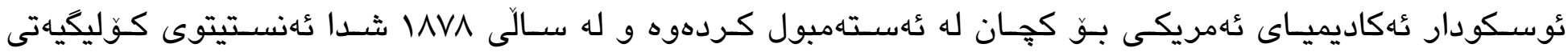

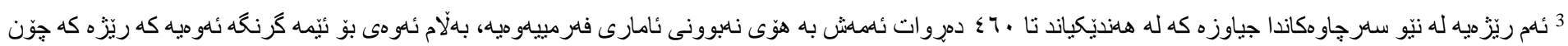
زيادى كردووه نئه 


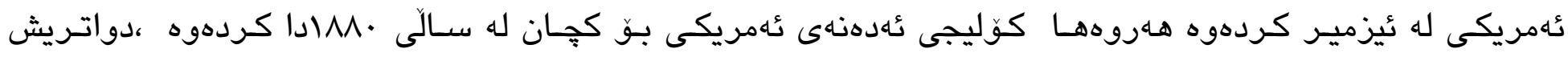

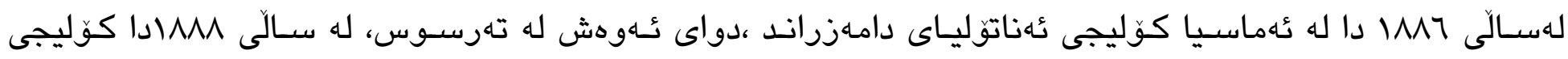

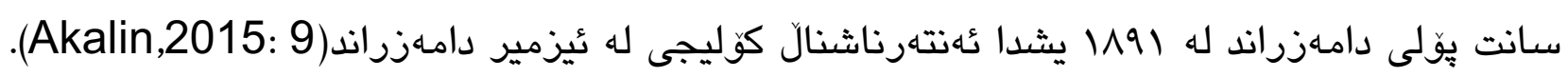

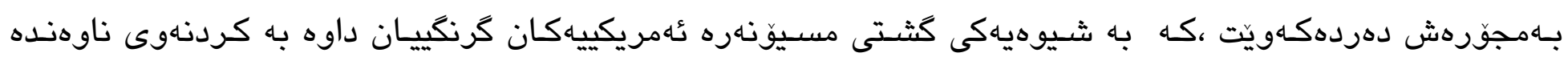

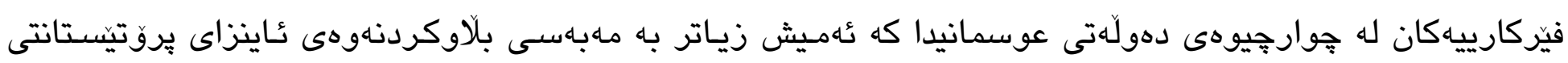

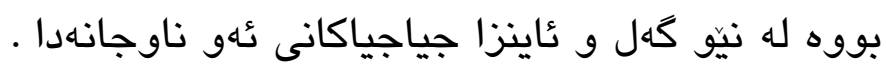

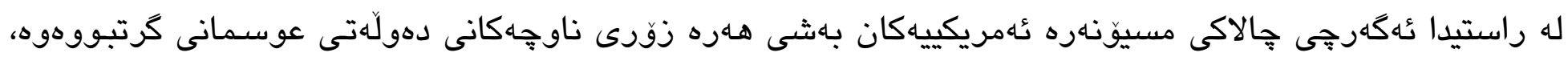

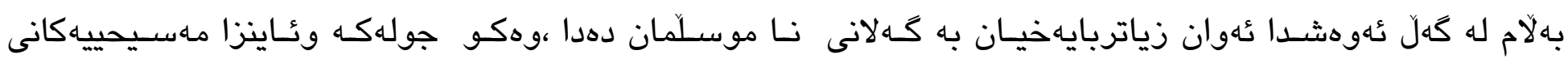

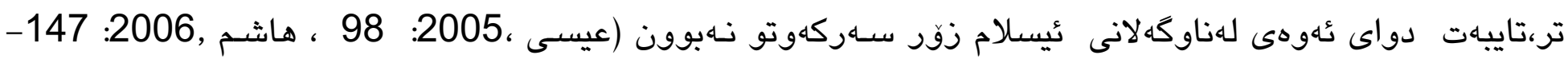

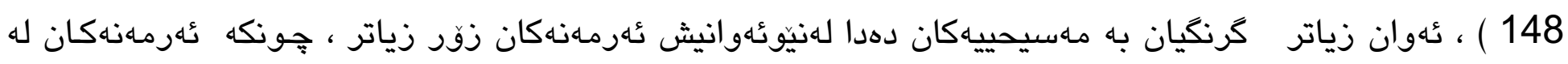

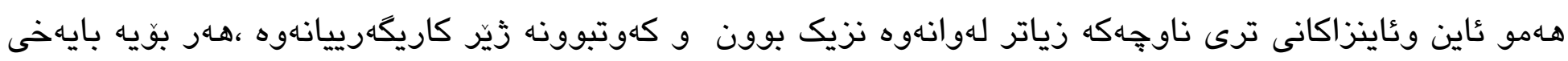

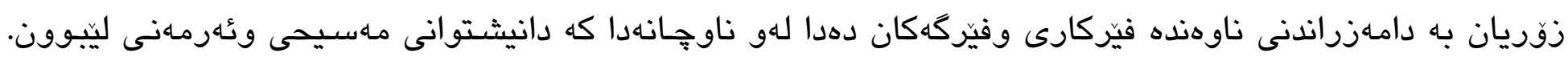

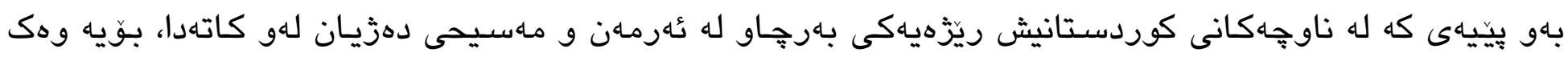

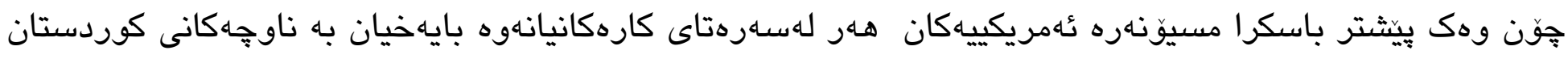

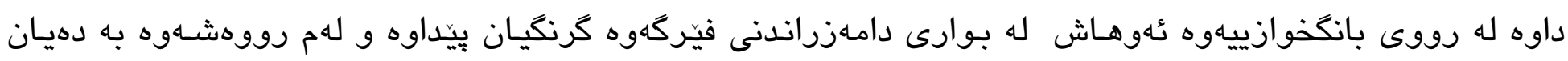

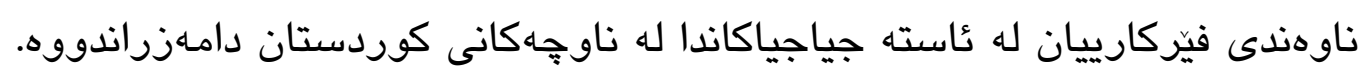

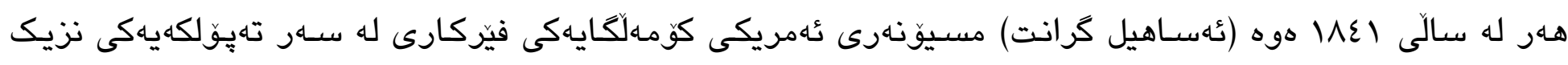

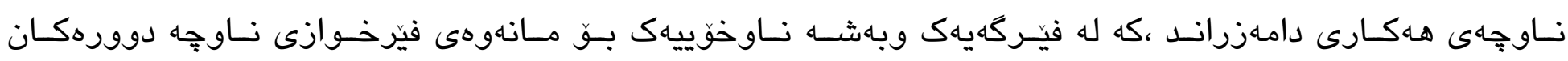

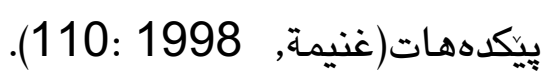

له نيوهى دووهمى سهدهى نوزدهوه له شارى موسل دوو فيّركه لـه لايسهن مسيوّنهاه ئهمريكييهكانهوه كرانهوه ، كه

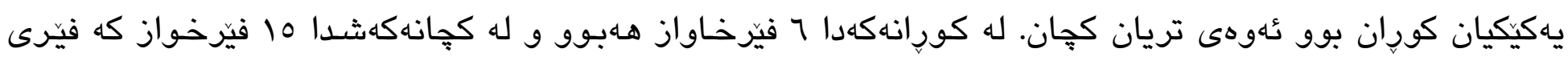

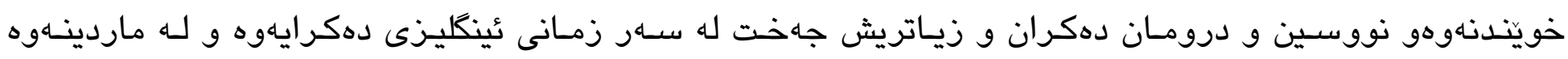

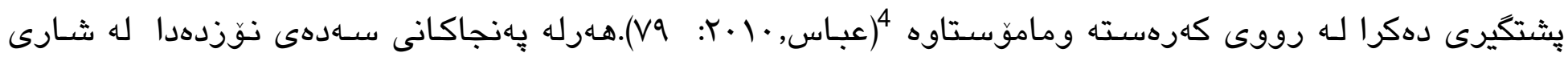

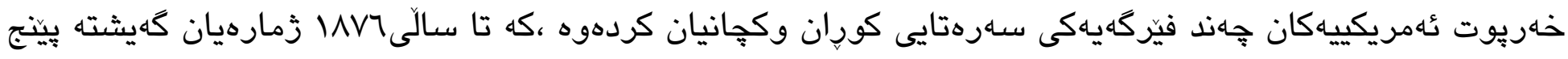




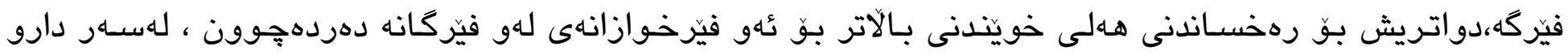

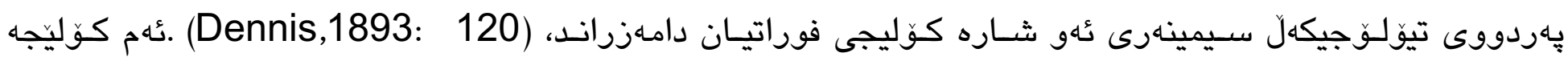

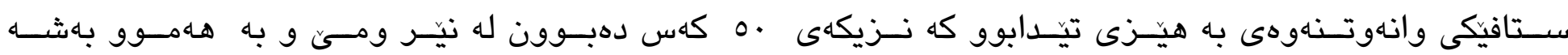

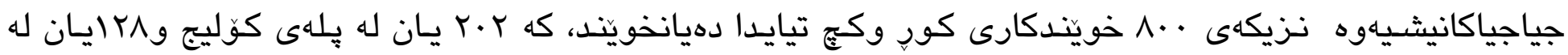

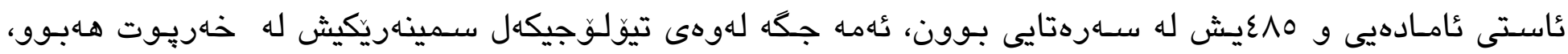

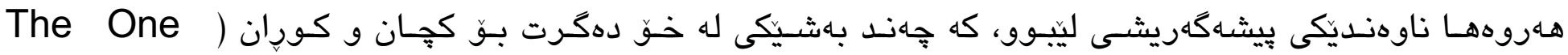
.(Hundredth...,1910: 122

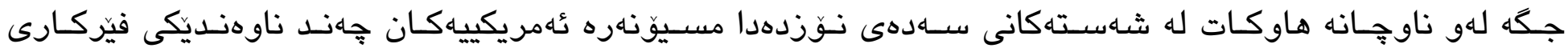

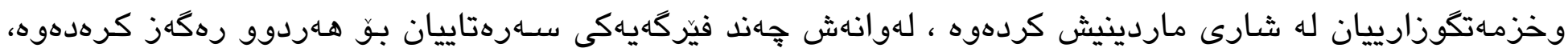

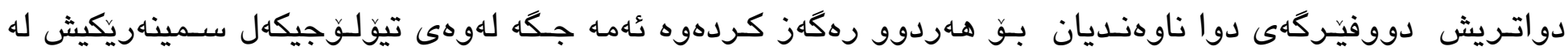

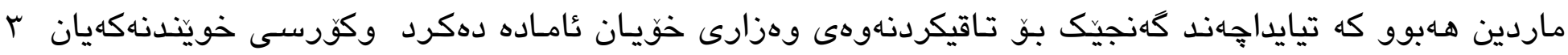
تيّرمى ^ مانكى بوو(The One Hundredth...,1910:123).

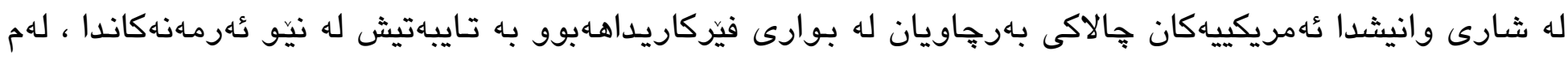

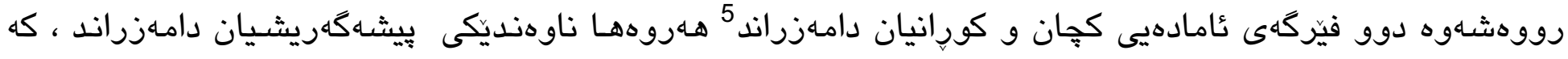

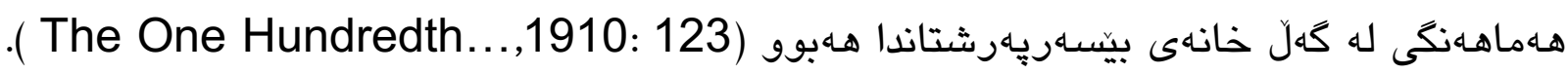

له شارى مهراشيش مسيوّنهرى ثٔهريكى تيوّلوجيكهل سيمينهرى مسيوّنهرى و كوليجى كجانى مسيوّنهرى هـروهها

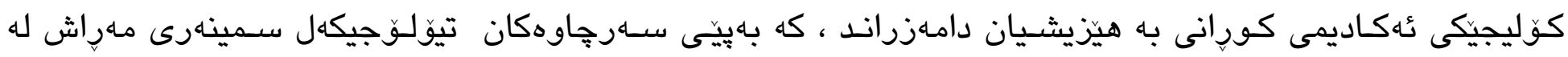

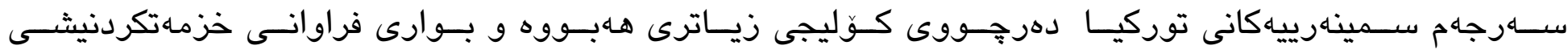

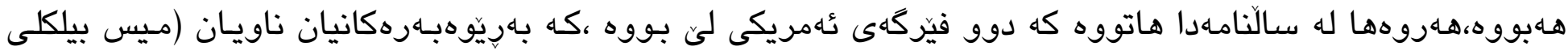

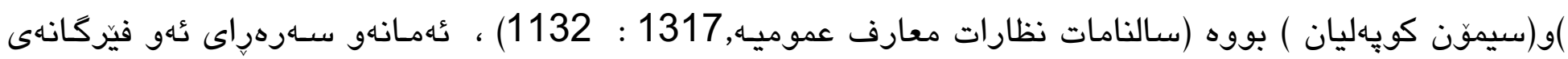

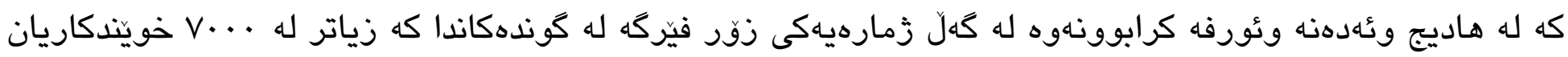

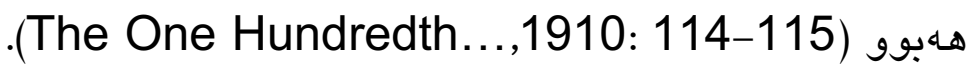

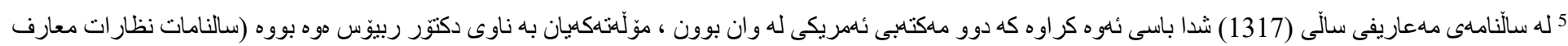
عموميه, 1317 : 1427 ) 


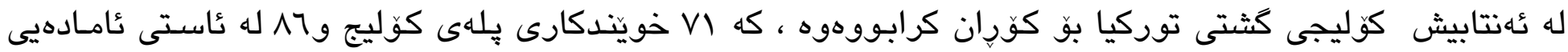

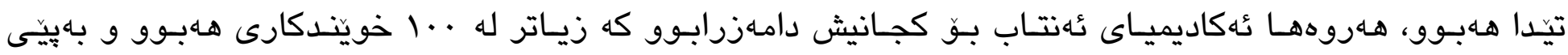

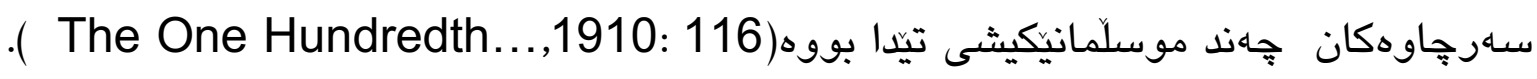

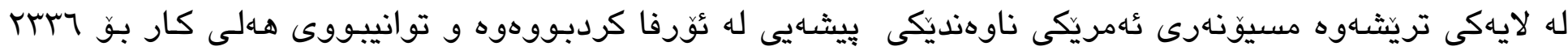

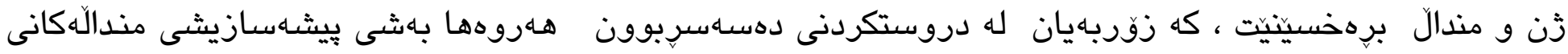

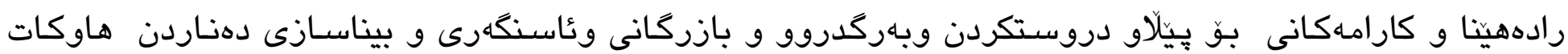

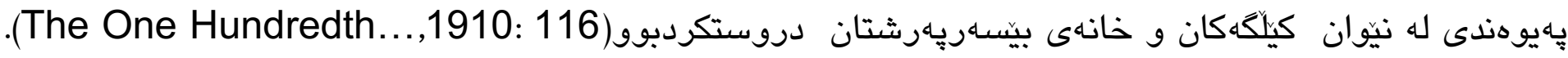

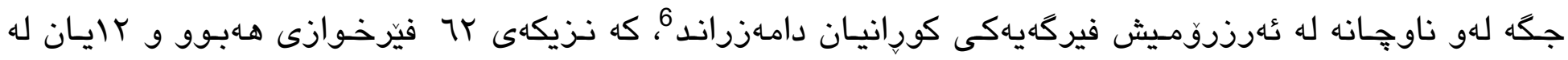

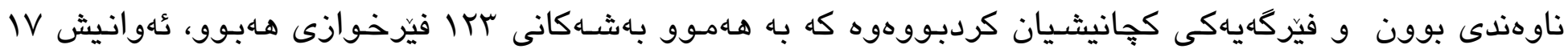

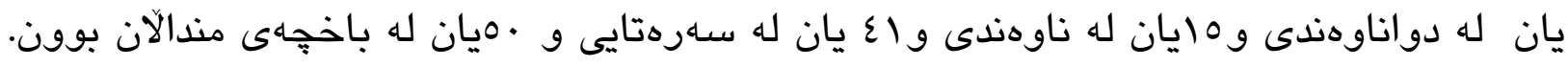
له بهتليسيش دواناوهندييهكى كورانيان دامهزراند ،كه بس فيزرخوازى هلهوو و ههنديكيان لهخانهى بيّسهاريهرشتانهوه

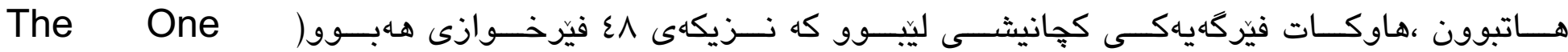
. (Hundredth...,1910:123

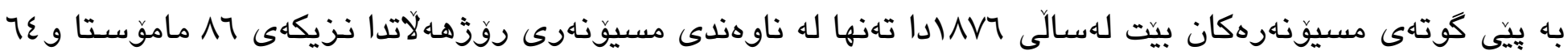
هاريكار هـبوون (Umit 2014: 30) بكنئ)

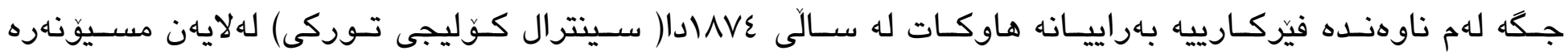

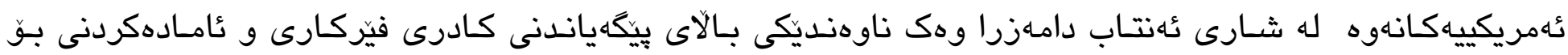

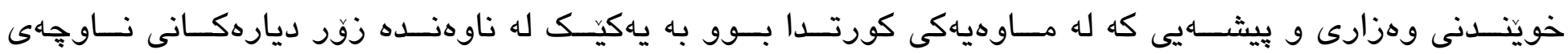

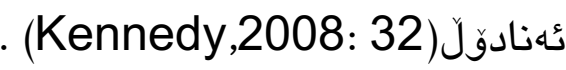

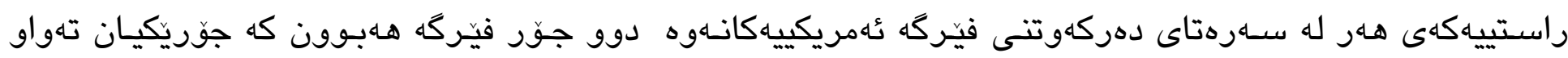

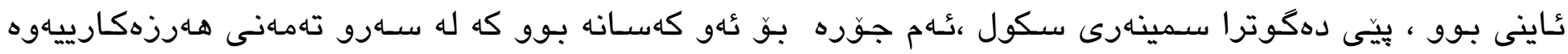

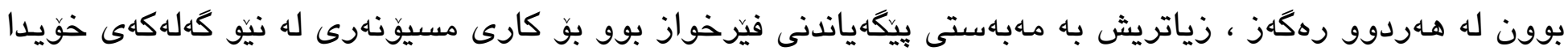

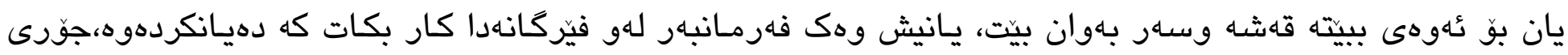

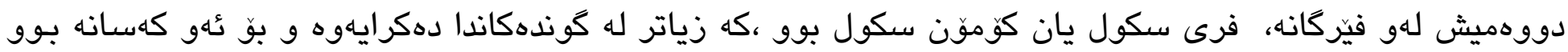

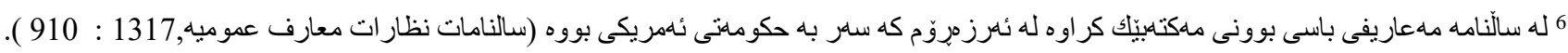




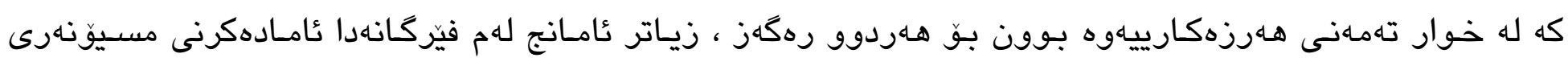

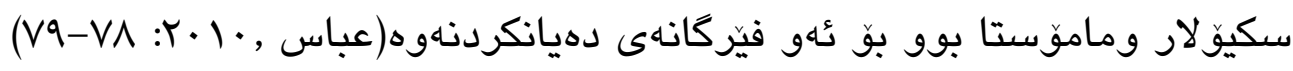

سهبارهت بهو بابهتانهى لهو فيّركانهدا دهخويندران به شيوهيهكى كثتى بوّ نيّر ومسي بريتى بوون له كتيبى بيروّز ،

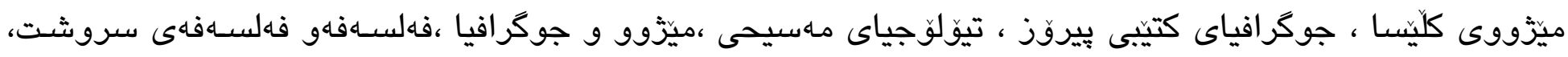

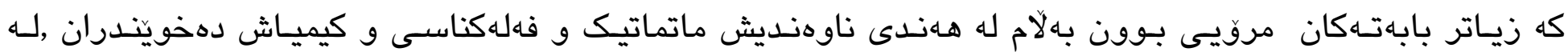

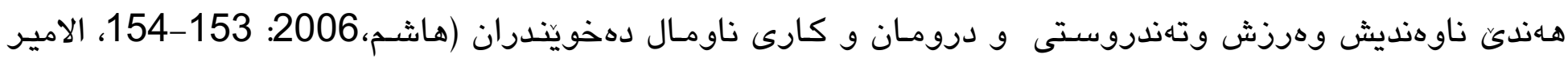

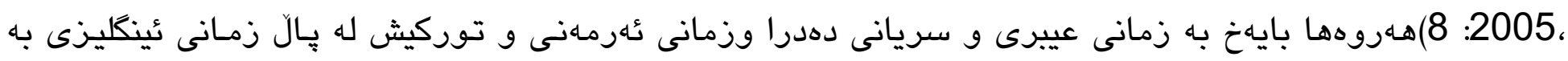

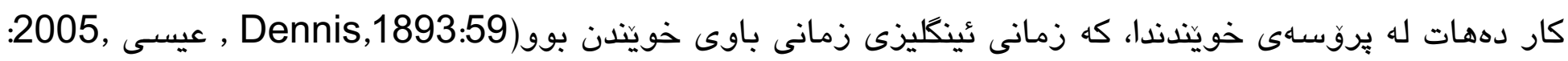

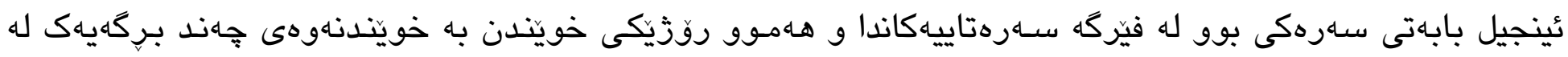

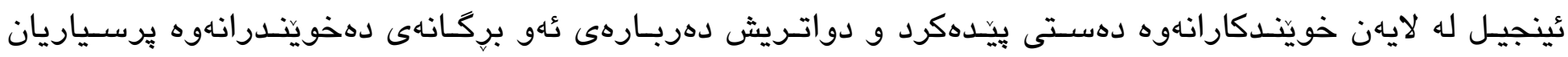

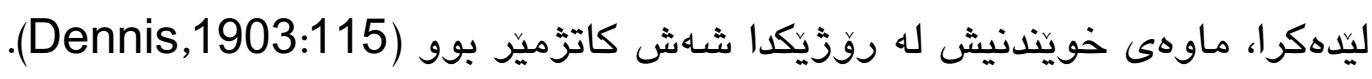

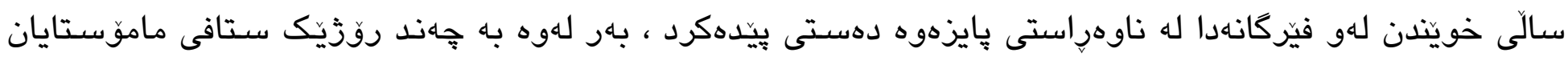

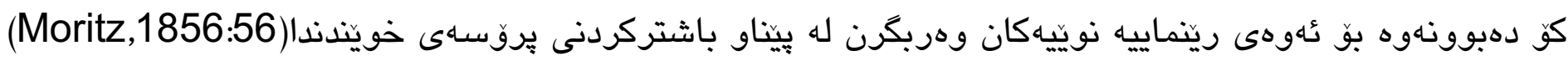

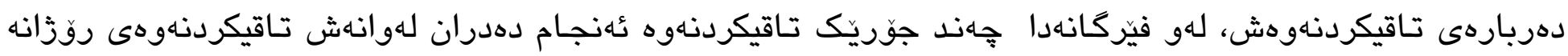

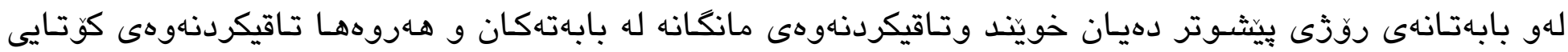

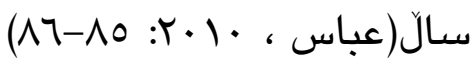

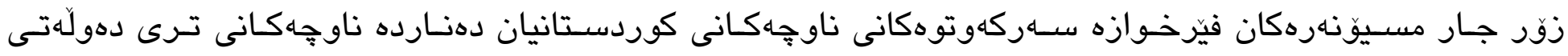

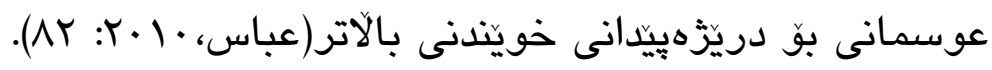

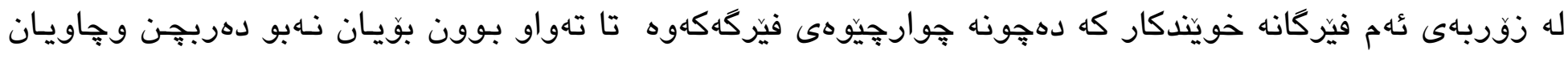

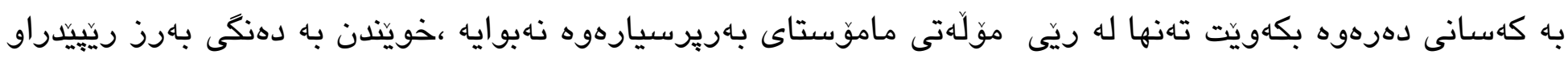

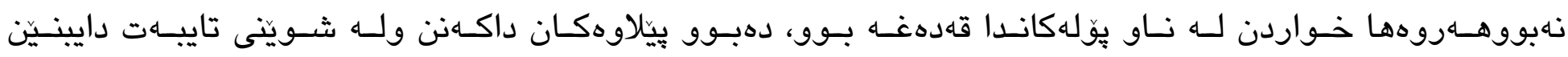

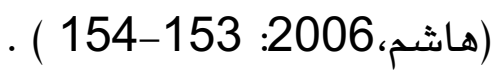




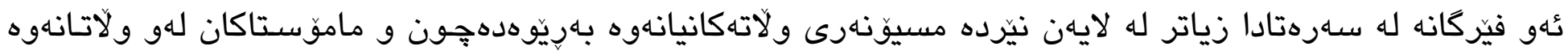

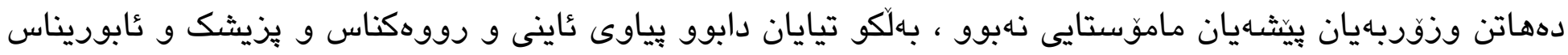

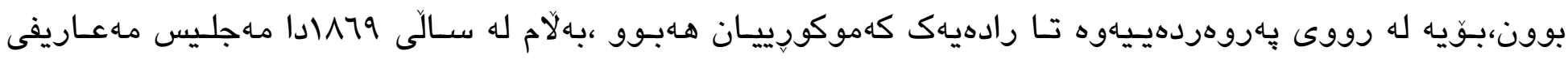

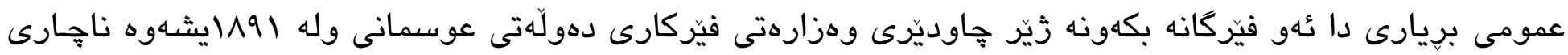

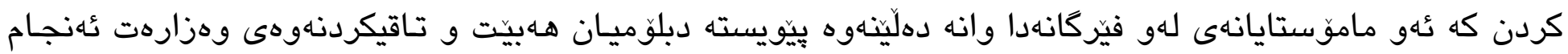

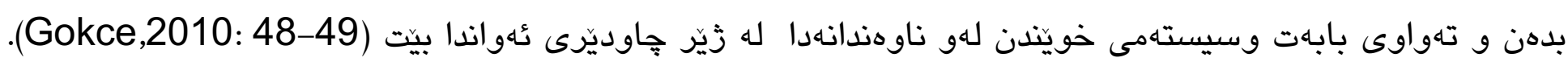

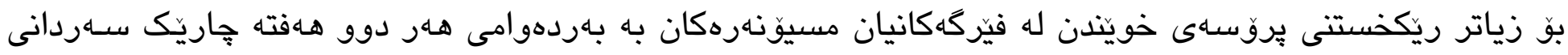

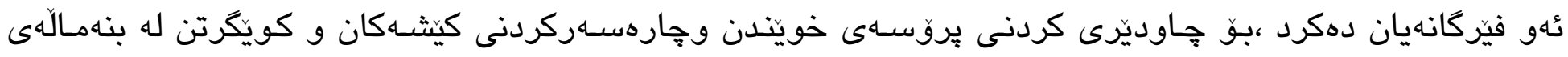

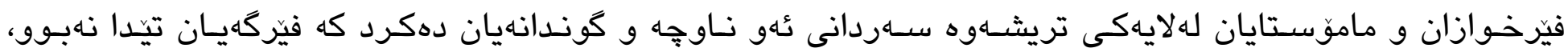

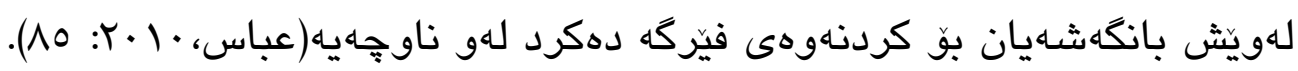

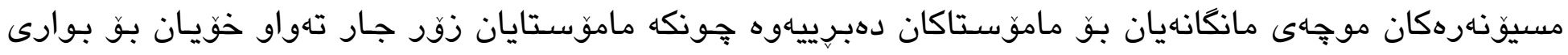

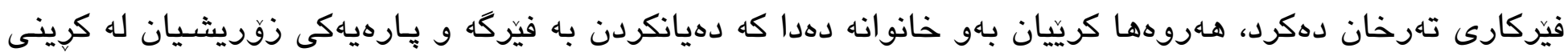

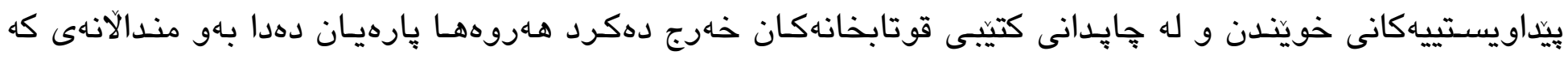
دوخى داراييان باش نهبوو و جل وبهركيان بو دهكرين(عباس، • • •r: 10).

بهامجوردش دهردهكهويّت كه ناوجهكانى كوردستانيش وهك ههموو ناوجهكانى ترى دهولَّتى عوسمانى و بكره له

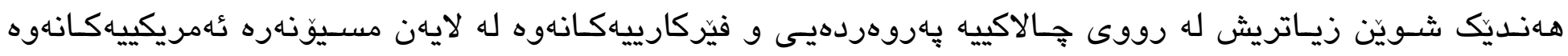

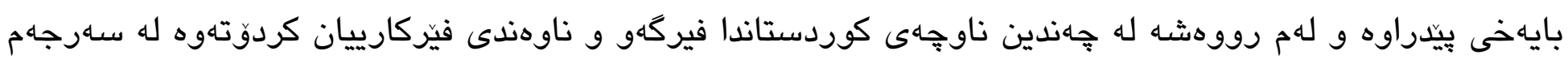
عاسته كاندا. 


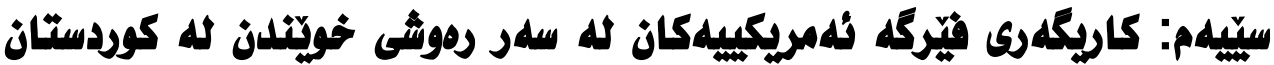

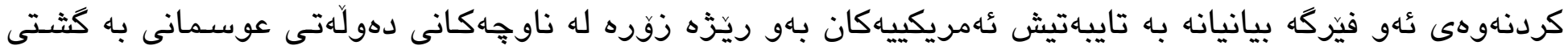

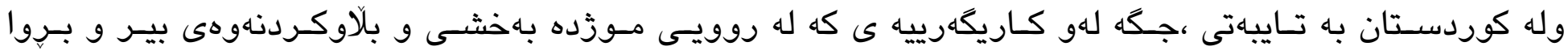

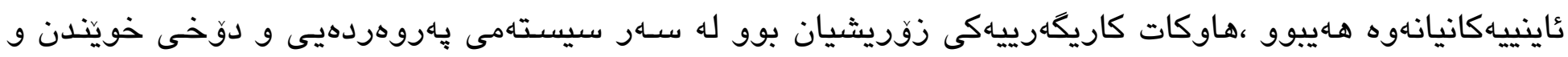

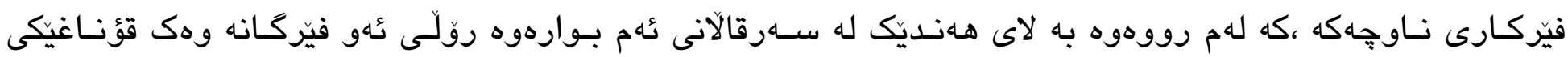

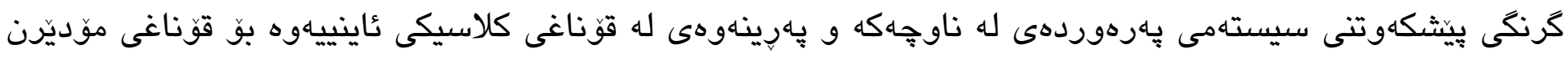

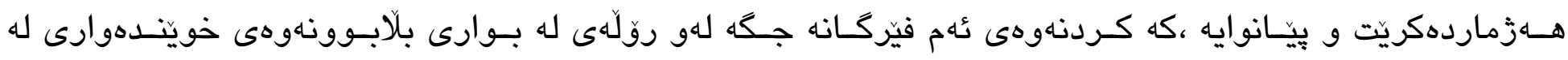

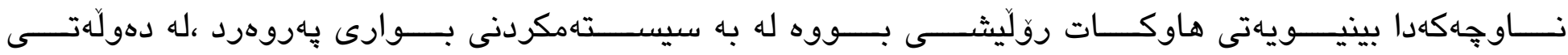

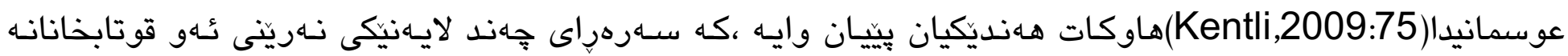

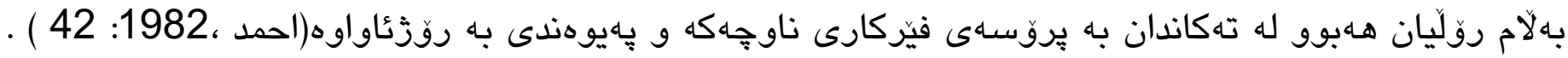

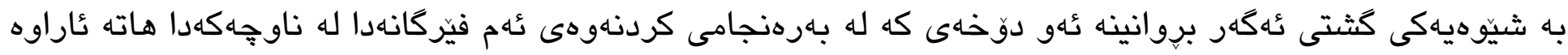

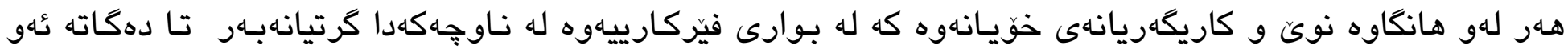

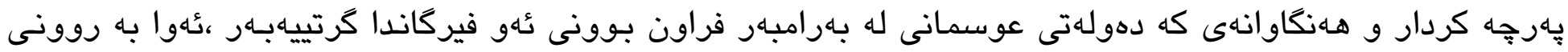

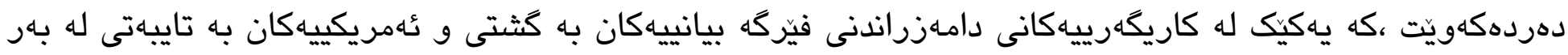

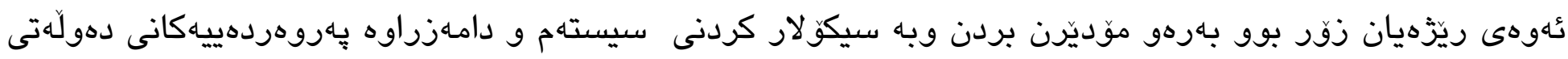

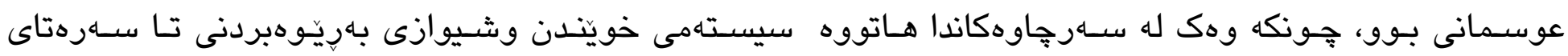

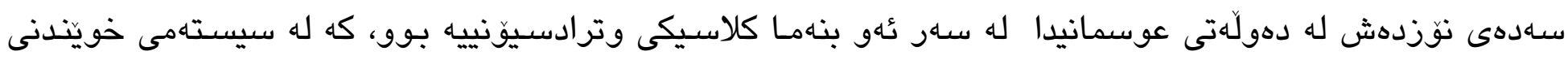

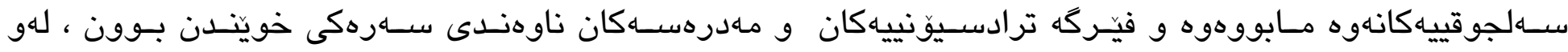

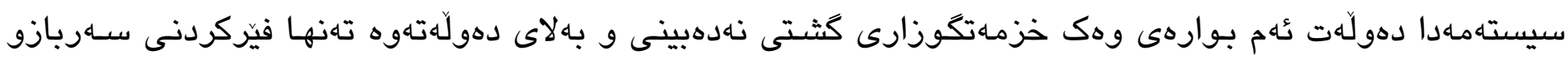

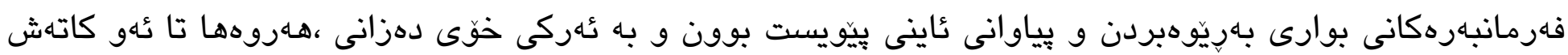

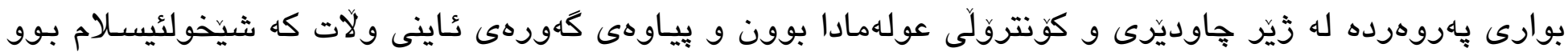

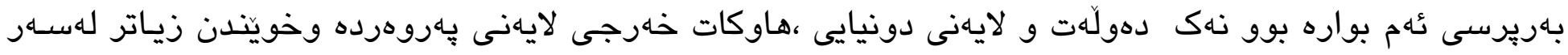

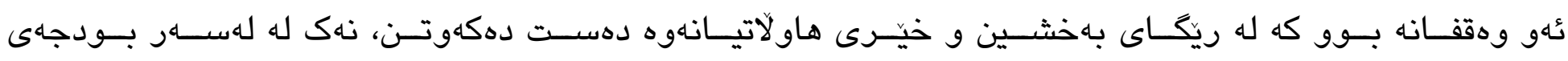

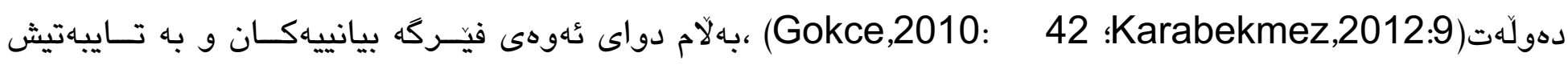

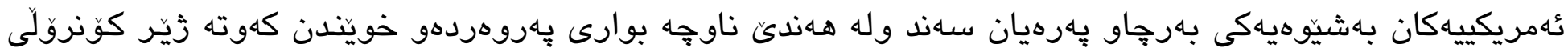

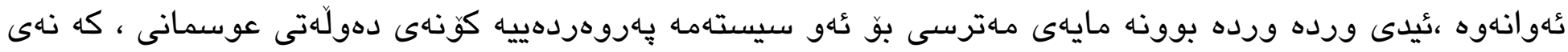




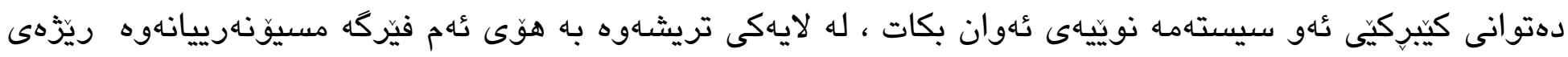

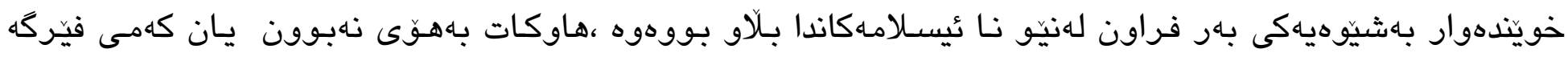

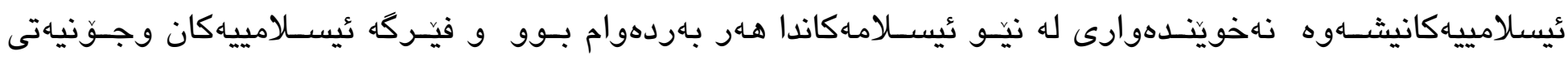

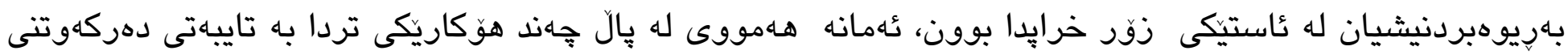

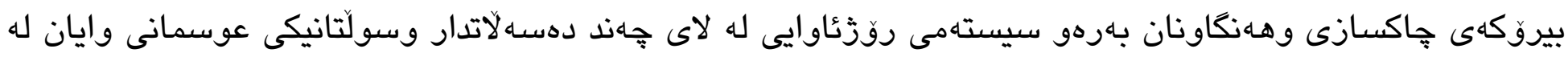

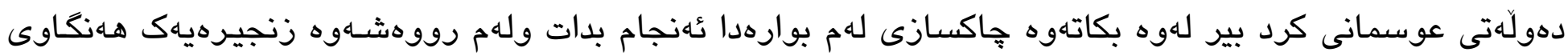

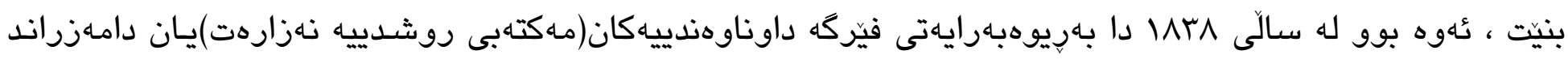

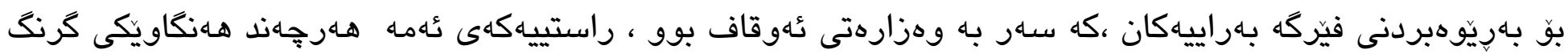

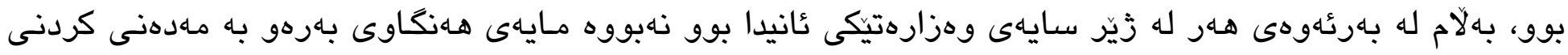

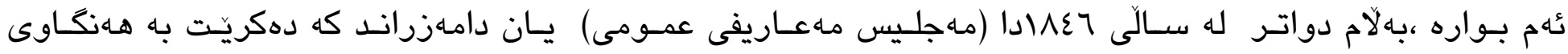

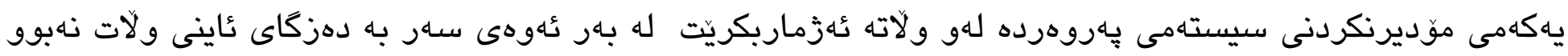

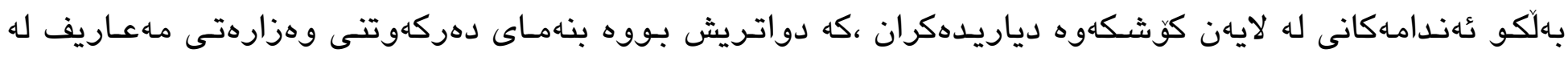

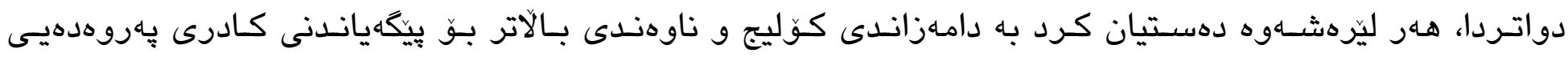

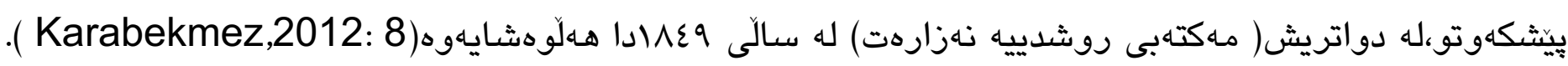

لهلايهكى تريشهاوه هـر له بهرامبهر ئهو فروانبوونهى فيّركه بيانى و نا ئيسلامياندا دهولّت هـولَيدا بشتيوانى زياترى

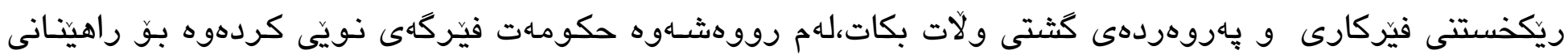

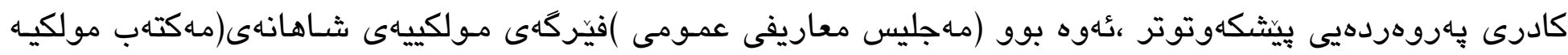

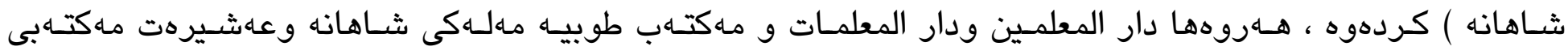

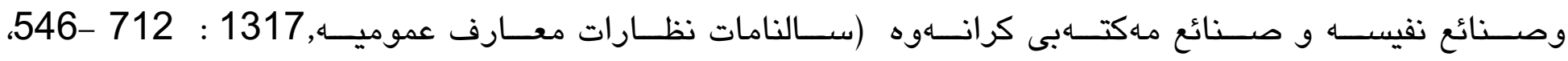

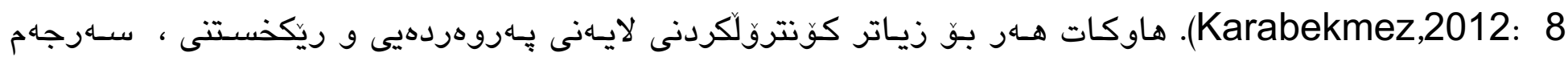

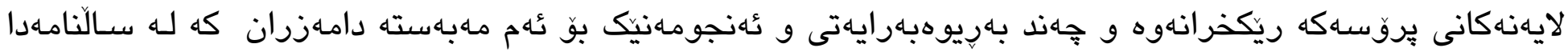

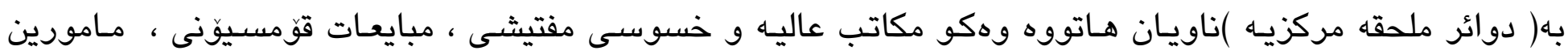

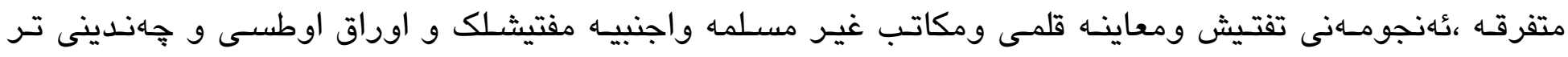

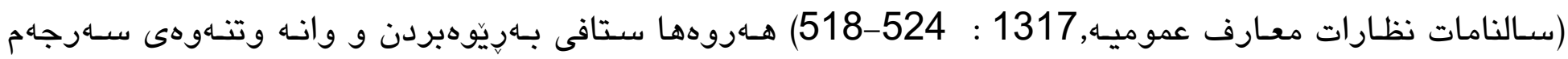

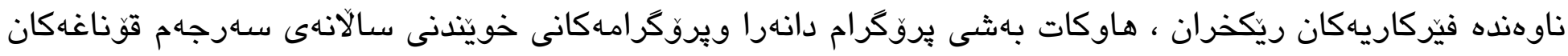

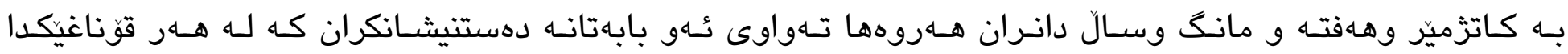

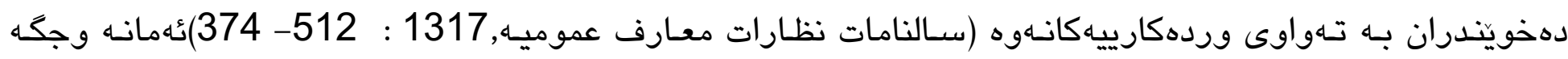




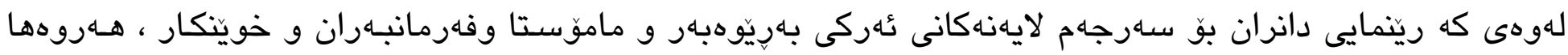

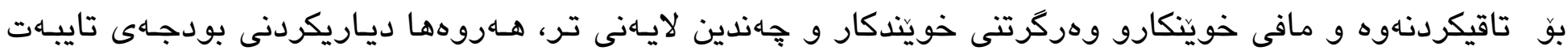

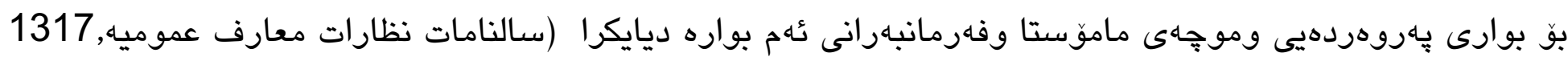
(320- 374 :

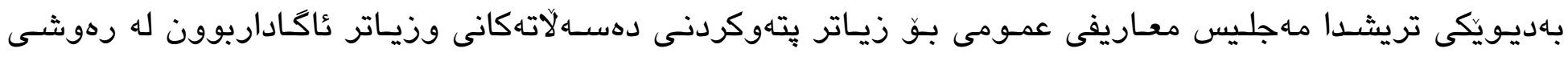

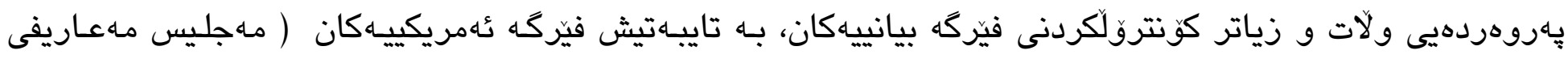

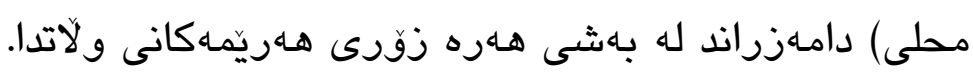

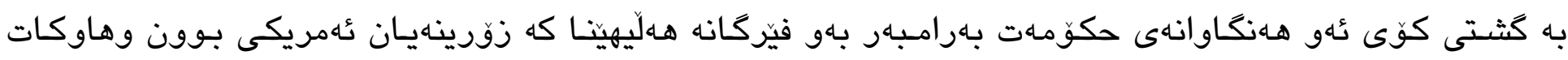

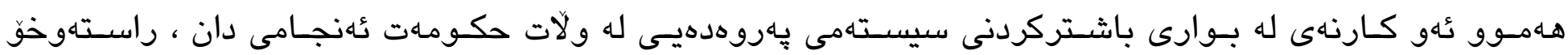

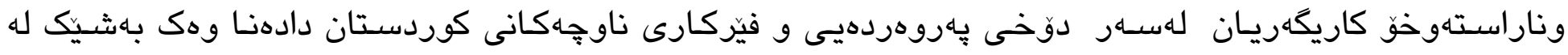

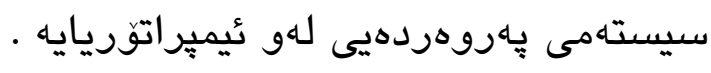

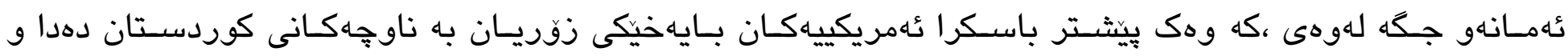

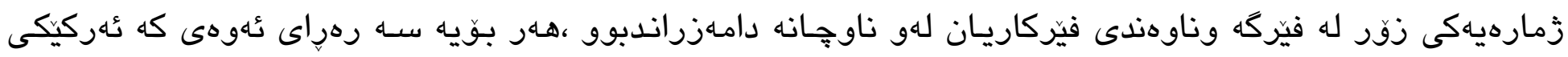

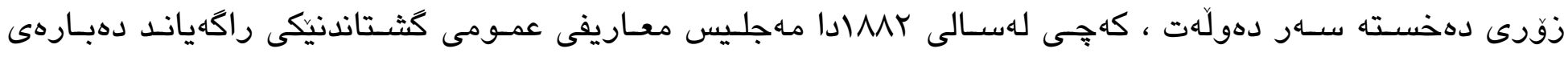

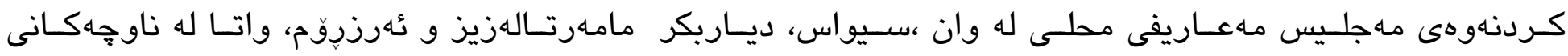

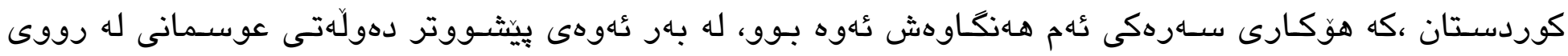

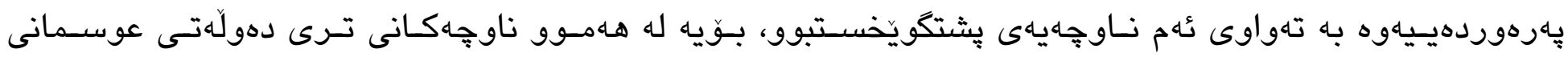

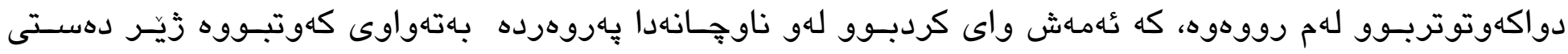

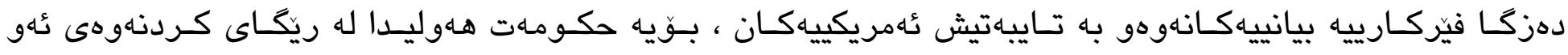

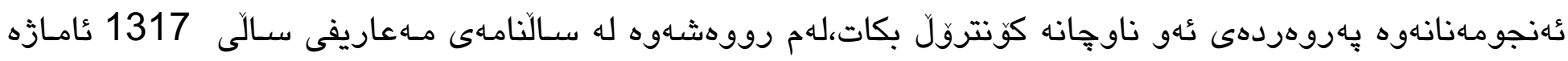

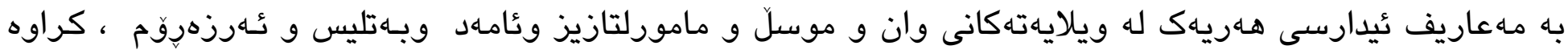

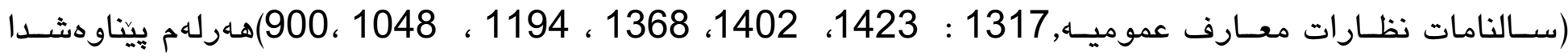

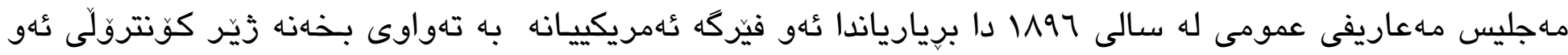

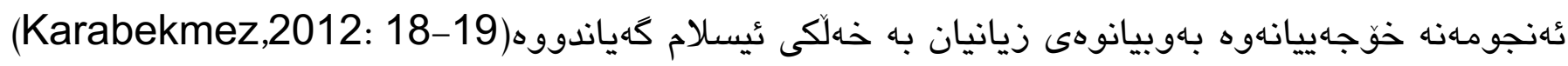


له لايهكى تريشهوه زورىى عُهو فيرّكانهو جالاكيان و يِيشكهوتووييان و سهرنج راكيشيان له رووى بابهت وبالهخانه

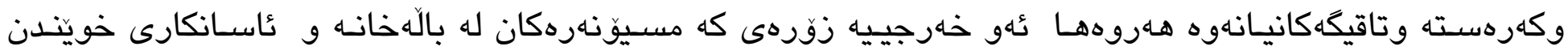

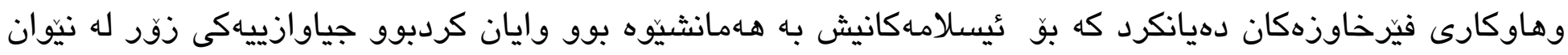

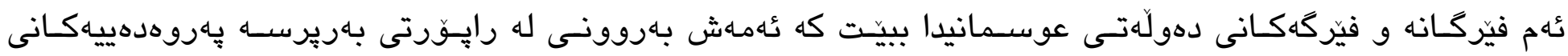

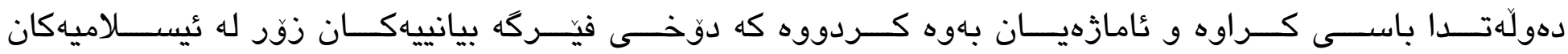

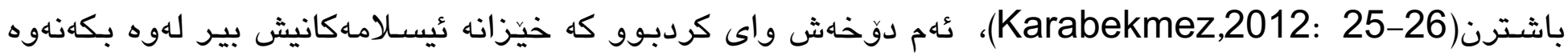

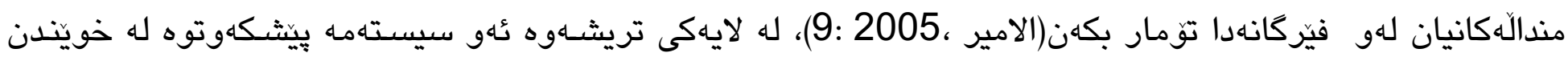

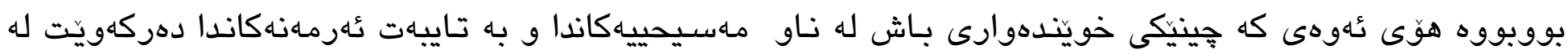

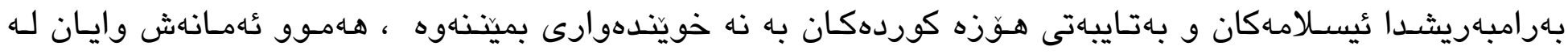

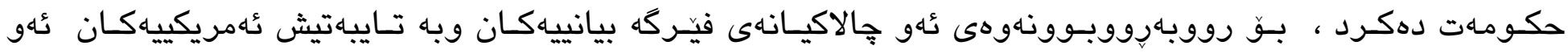

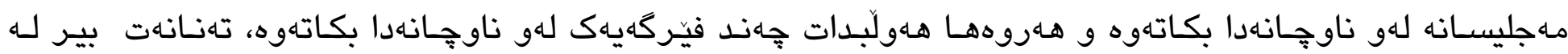

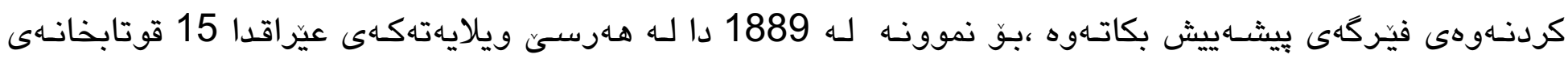

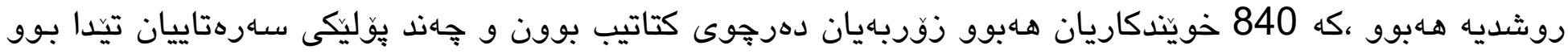

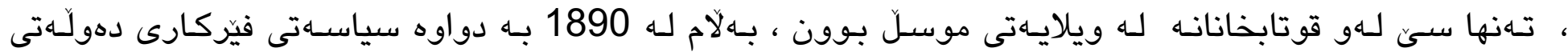

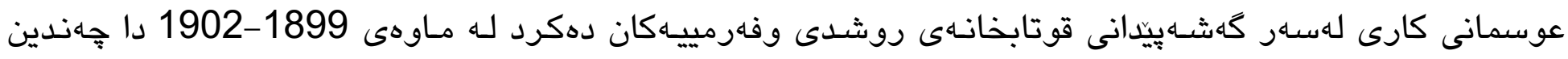

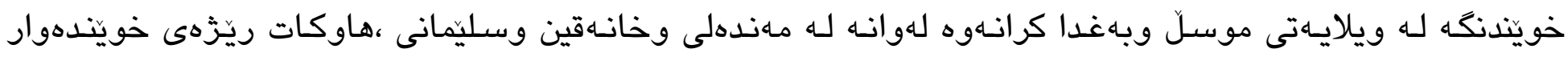

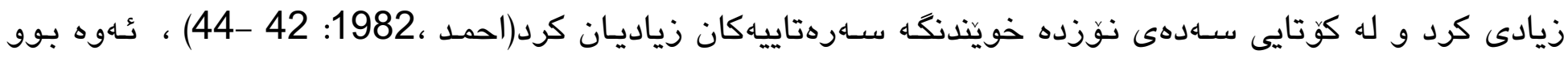

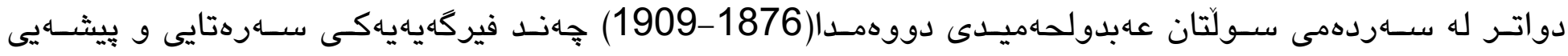

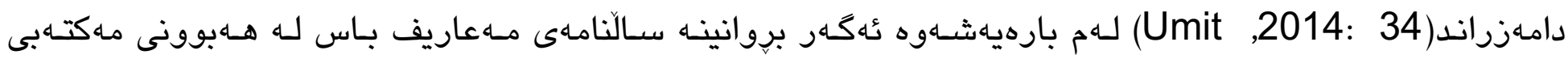

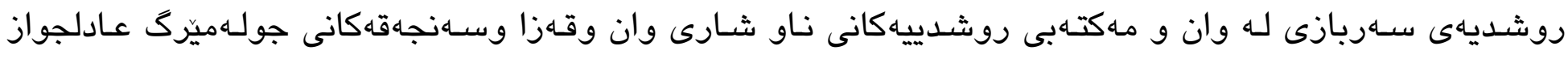

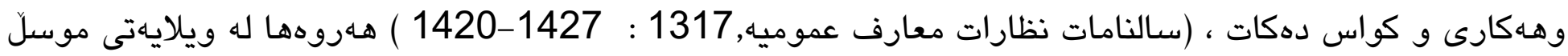

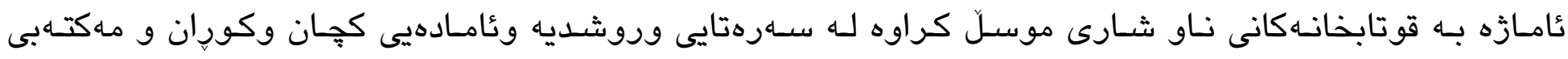
روشدييهى هـوليّر وسهلآحيه وماكتهب روشدييهى سهربازى له سليمانى و مهكتهب روشدييهى سليمانى وكهركوك

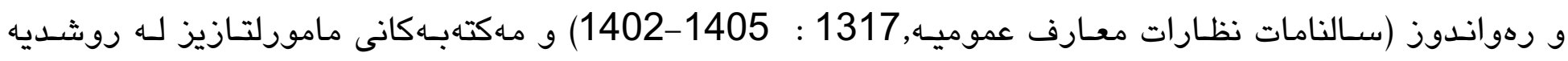
وروشديهى سهربازى و روشديهى كجان توماركراون (سالنامات نظارات معارف عموميه, 1317 : 1372-1368)

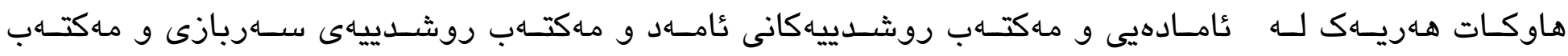

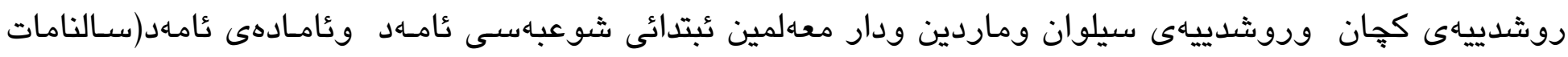




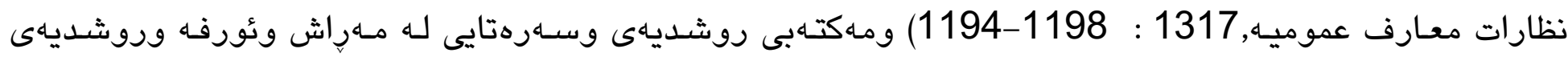

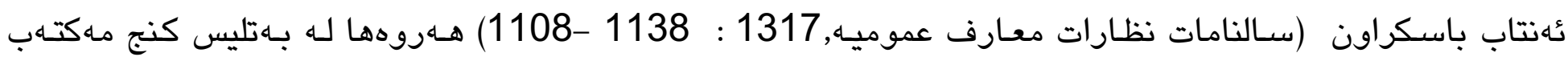

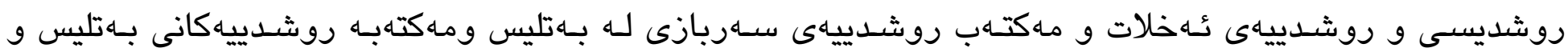

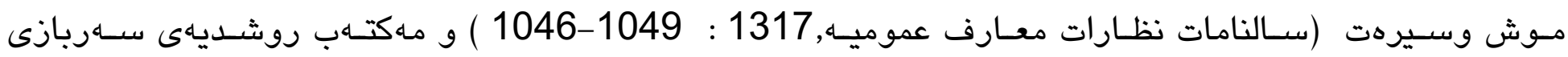

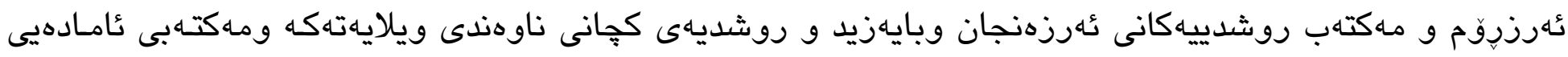

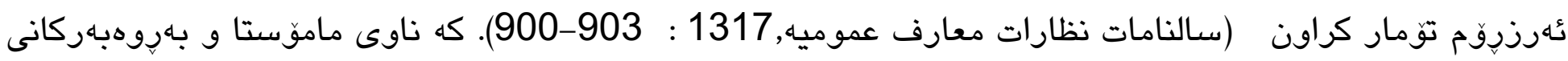

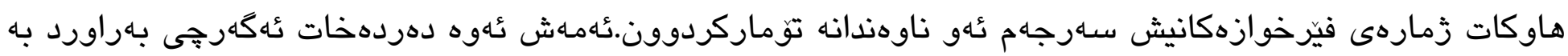

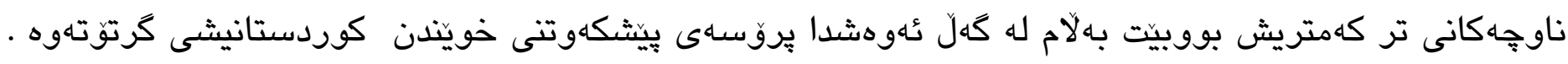

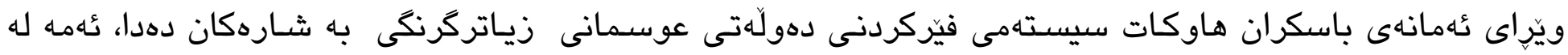

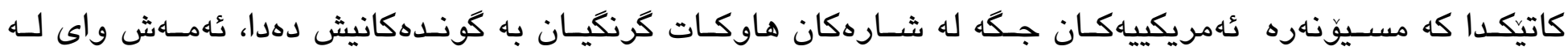

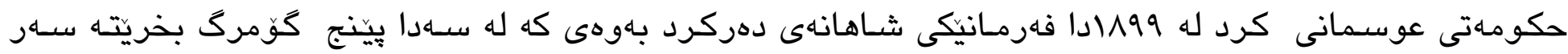

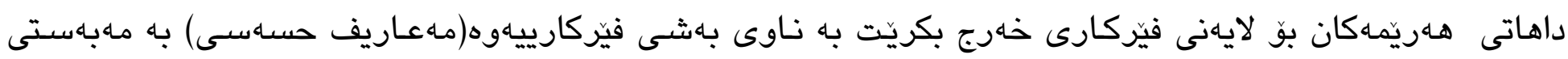

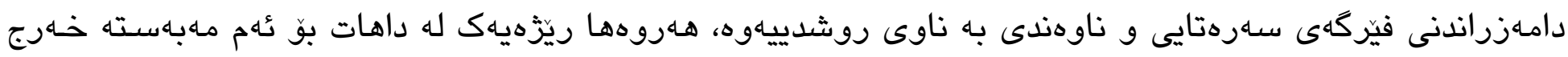

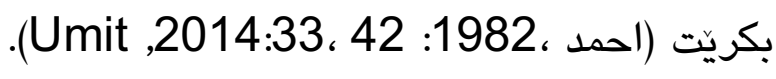

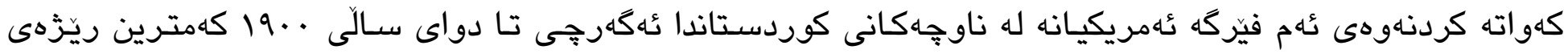

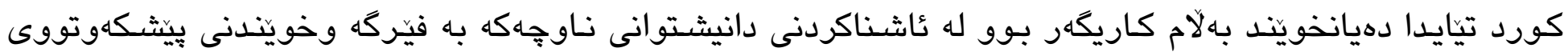

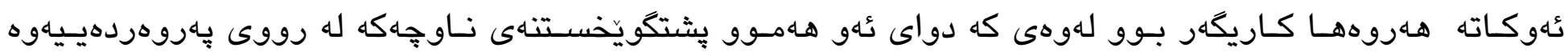

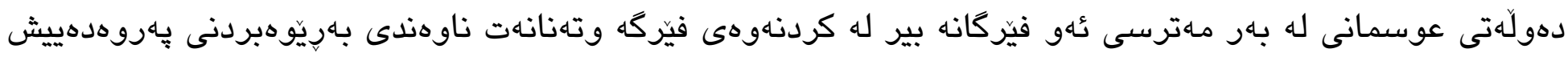

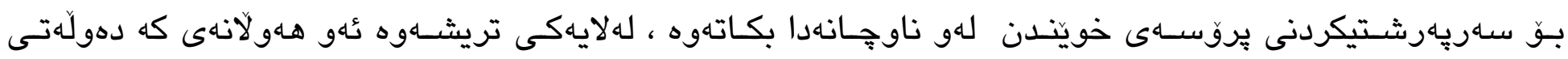

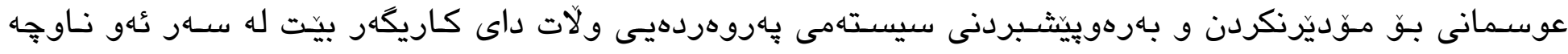

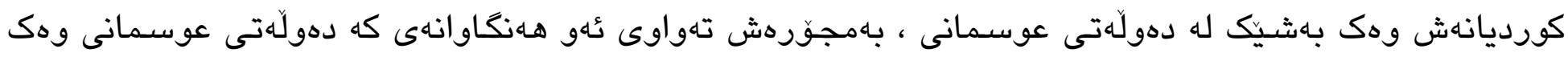

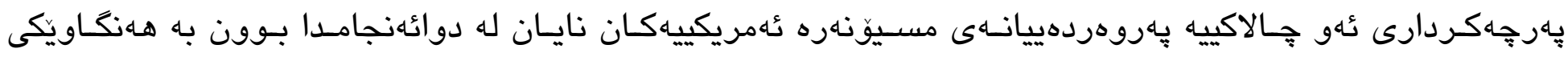

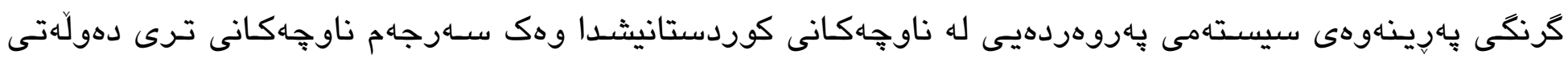

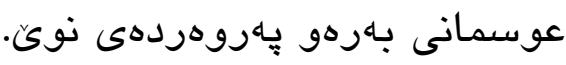

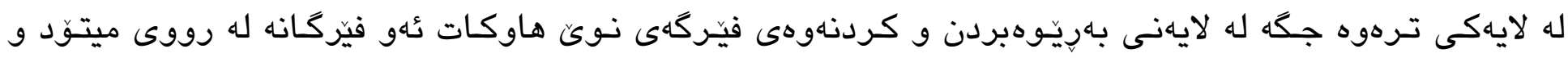

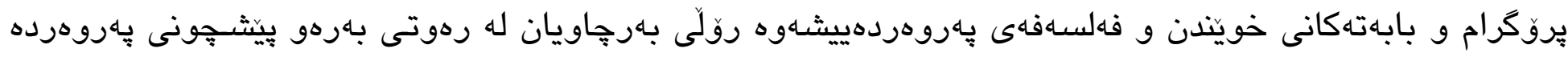




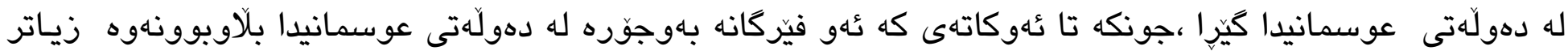

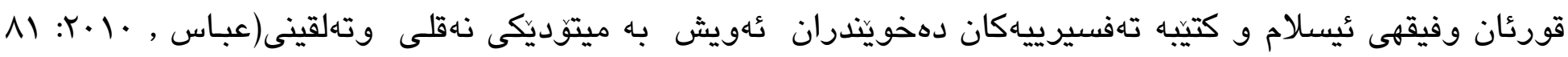

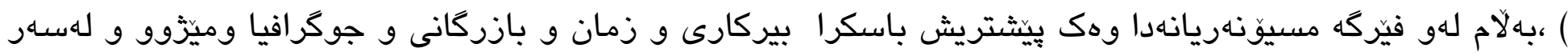

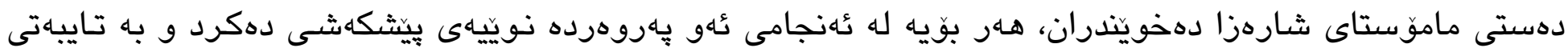

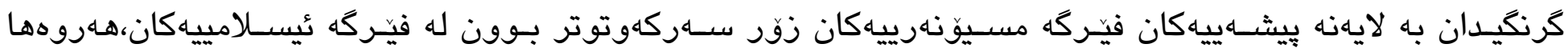

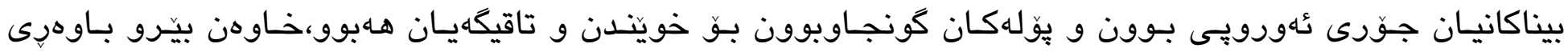

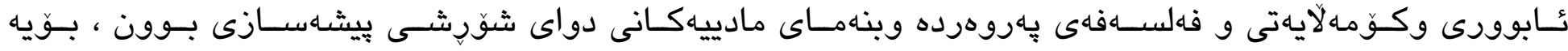

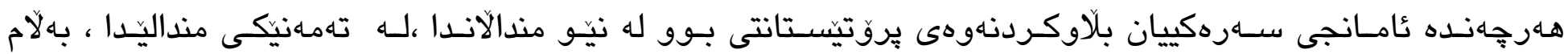
مندالّكانيان له سهر زيانى دواى قوتابخانه رادهينيا هـروههـا كَرنكيان به زمـانه كانى سـريانى و عيبرى وبه زمانى

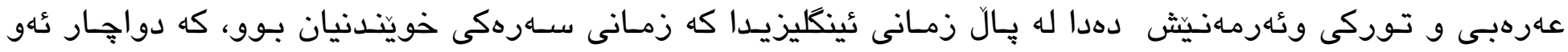

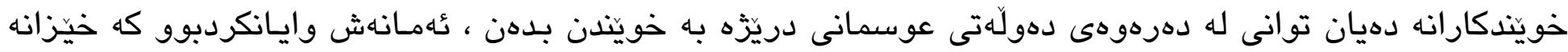

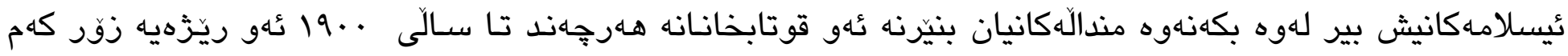

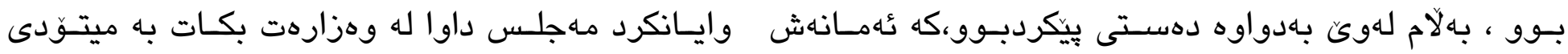

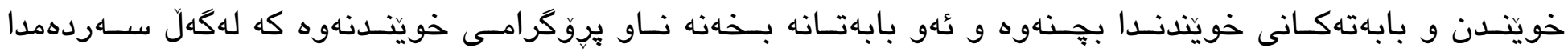

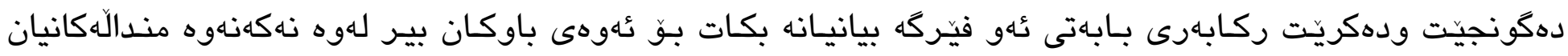

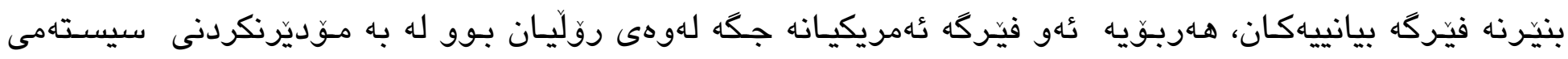

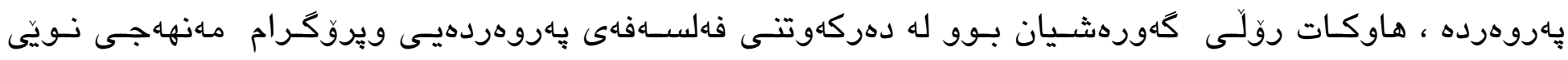

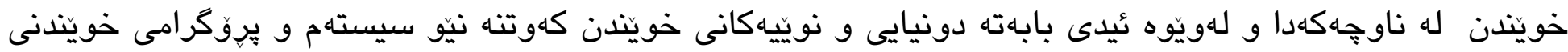

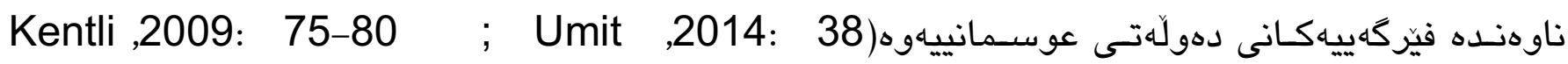

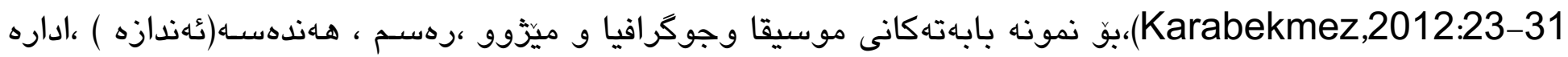

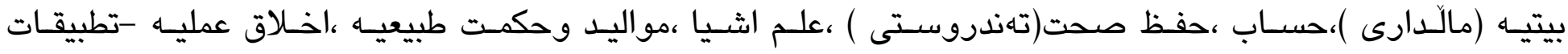
،اخلاق،اخـلاق نظريه،اصـول التعليم واداره مكاتب ،حسـن الخط،كتابت،قواعد عثمانيـه ،فارسى ،عـهرهبى ،علوم الدينى

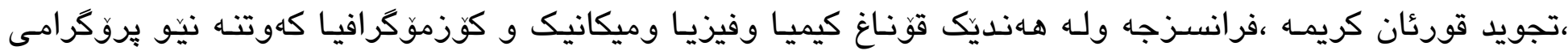

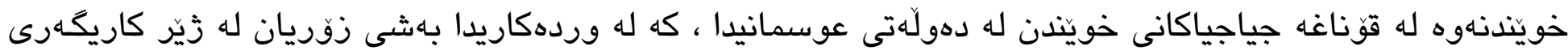

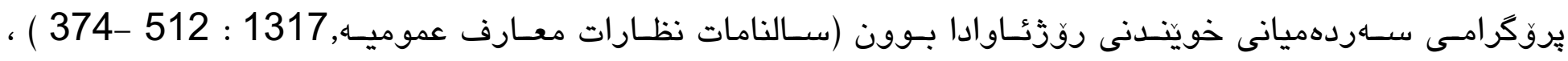

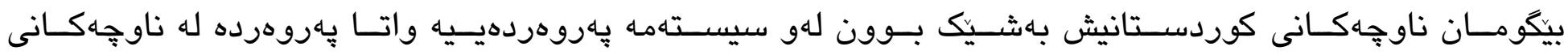
كوردستانيش لهو بِيشكاوتنانه بيّبهش نهبوو. 


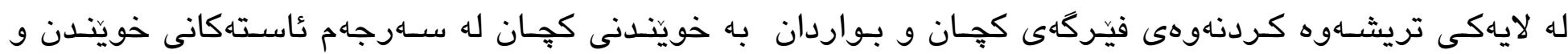

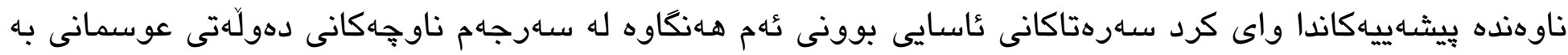

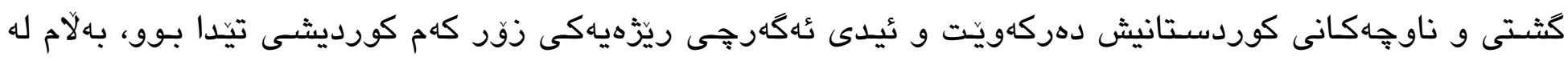

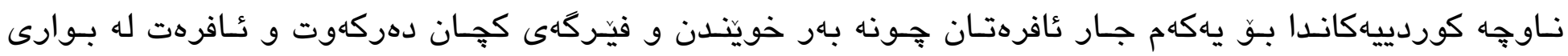

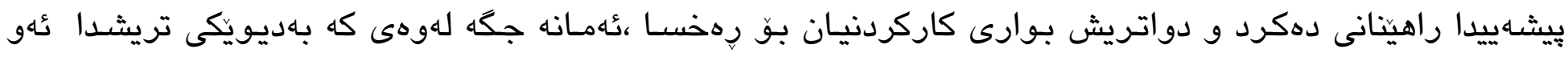

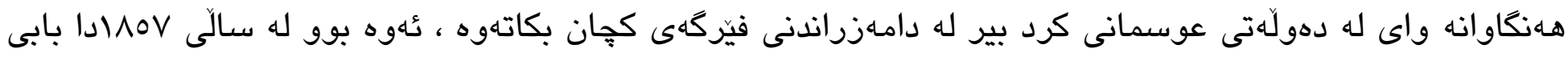

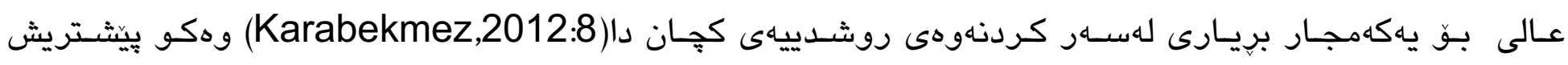

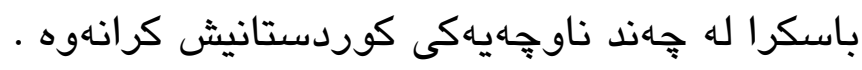

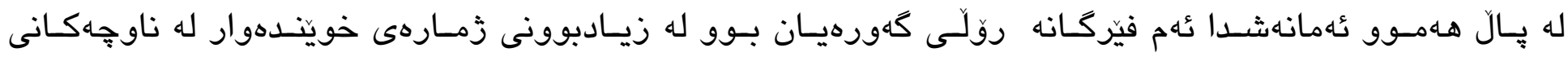

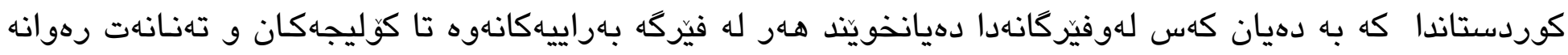

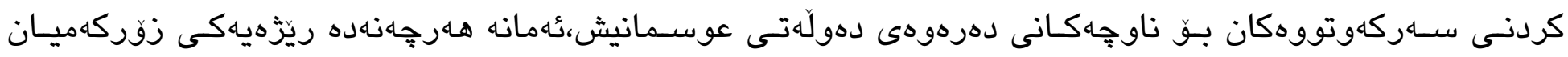

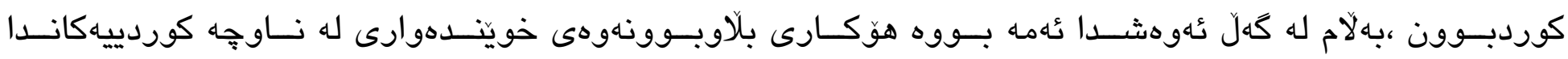

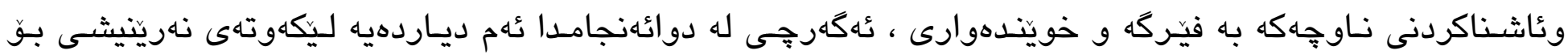

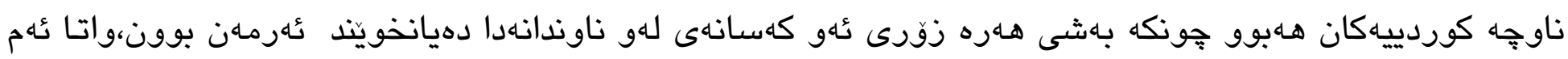

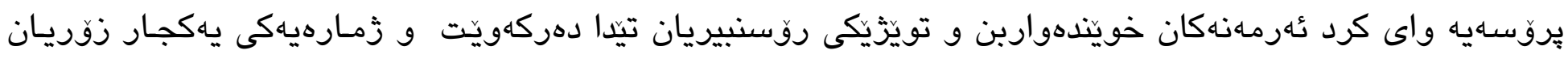

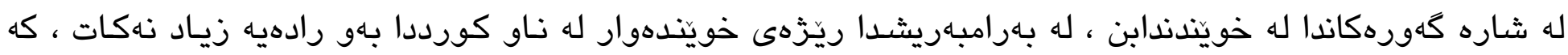

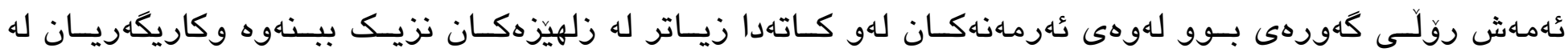

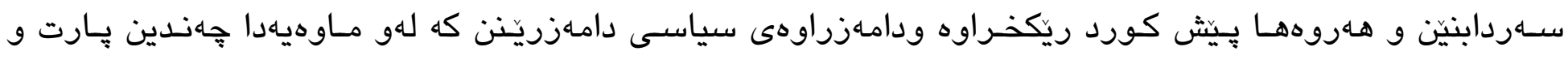

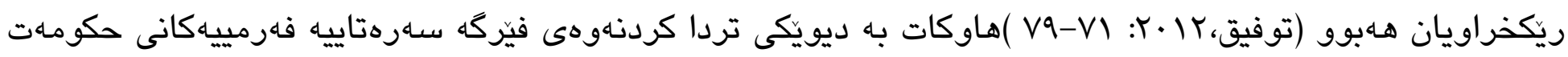

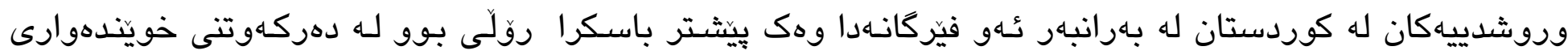

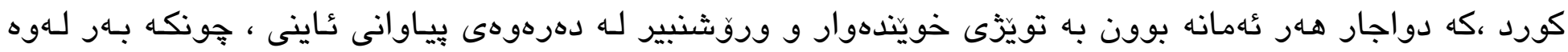

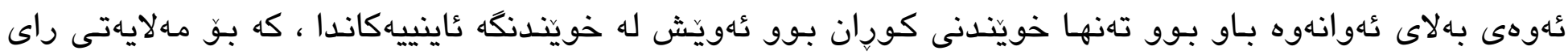

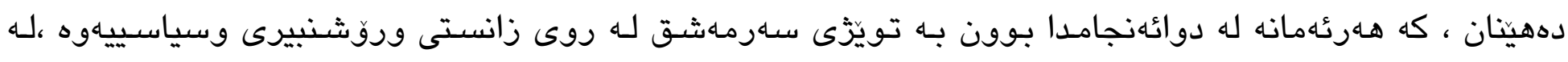

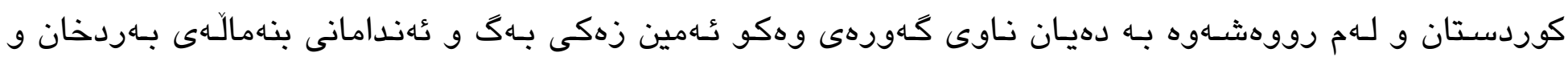

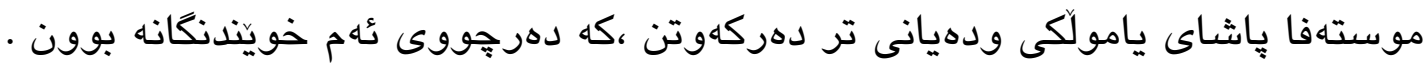




\section{ألهنجمام:}

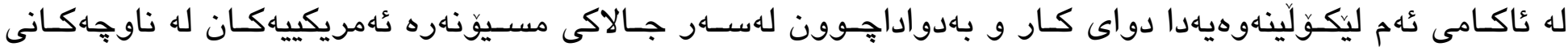

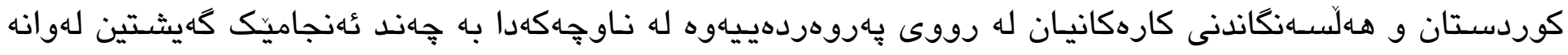

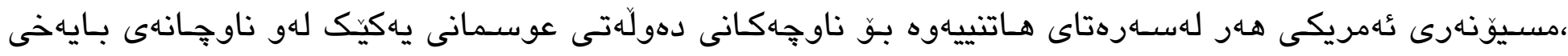

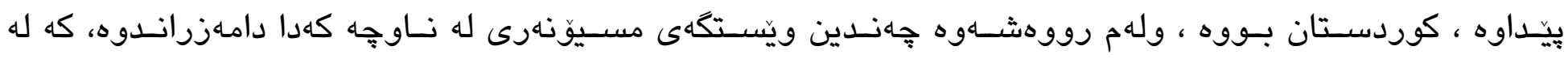

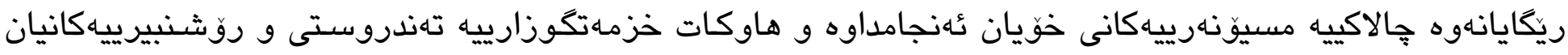

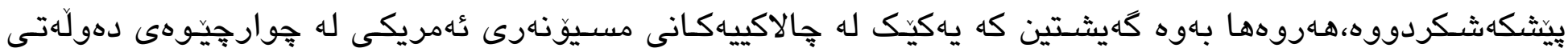

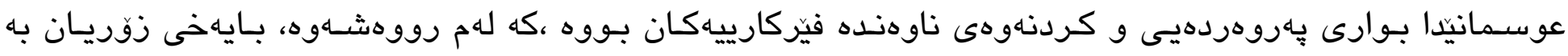

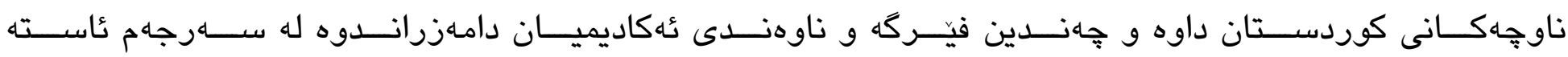

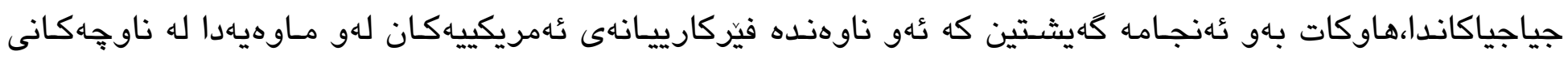

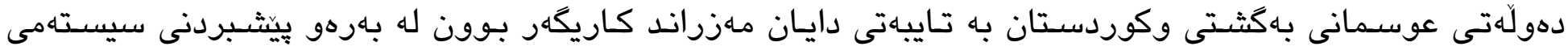

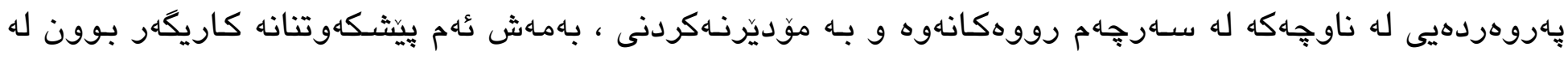

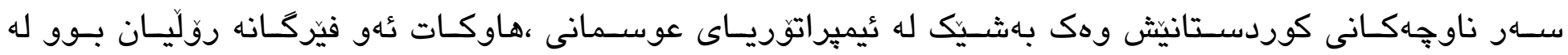

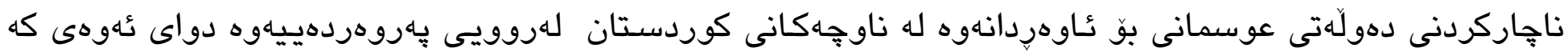

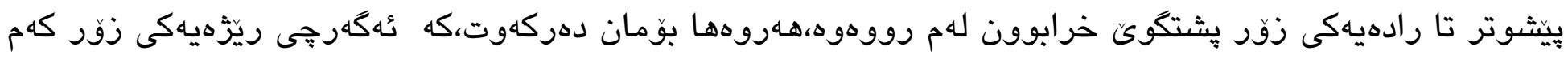

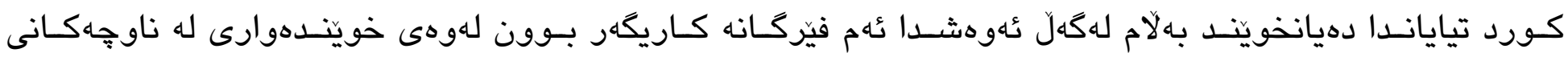

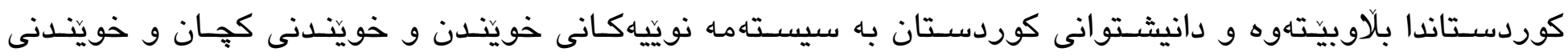
بينشاهيى عاشنا بكات. 


\title{
Schools and educational centers for American Missionary and their effects on the educational situation in the Ottoman Kurdistan in the nineteenth century
}

\section{Saman Hussein Ahmad}

Department of Social Sciences، College of Basic Education، University of Sulaimani, Sulaimani, Kurdistan Region,Iraq.

E-mail: Saman.abdullah@univsul.edu.iq

\begin{abstract}
:
After American missionaries arrived to the regions of Ottoman Empire in the beginning of the 19th century and when they started their activities, the Kurds as one of the nations who were living within the Ottoman Empire, attracted the attention of missionaries. Therefore they opened their office in the Kurdish cities and started their activities. As it has been known that most of the activities of American missionaries were intellectual and educational activities, as a result they opened many schools, professional schools and even they established universities in some cities of Kurdistan, many girls and boys studied in these schools.
\end{abstract}

This study is about (American Missionaries' educational centres in Kurdish cities in Ottoman Empire in $19^{\text {th }}$ century). This study attempts to illustrate the impact of these schools that were established by American Missionaries and how they were operated. This paper is divided into three parts. First part is about the appearance of American missionaries' activities in the region of Kurdistan. In this part we will try to briefly describe how they came to Kurdish regions and how they worked and what were their activities. The second part is about the American missionaries' educational centres in Kurdistan. It endeavours to show the educational activities of American missionaries in Kurdistan regions, and then it will illustrate the importance of these educational centres in Kurdistan regions. The third part is about the effect of American missionaries' educational centres on the situation of education in Kurdistan. It will evaluate the impact of these educational centres on the education in Kurdistan and on the situation of education in Kurdistan.

Key words: School, American Missionary, Kurdistan, Education. 


\section{المدارس والمراكز التعليمية للتبشير الامريكي و اثارهم علي الوضع التزبوى والتعليمى في كوردستان الثثماني في القرذ التاسع عشمر عئر}

\section{سامان حسبيز احمل}

قسم العلوم الاجتماعية ، كلية التربية الأساسية ، جامعة السليمانية ، السليمانية ، اقليم كردستان العراق. Saman.abdullah@univsul.edu.iq ئيمهيل

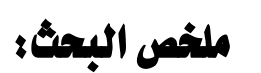

بعد ان وصل المبشرون الامريكيين الى مناطق الو اقعة تحت سلطة الدولة العثمانية في بدايات القرن الثاسع عثر و وبدأو بنثاطاتهم

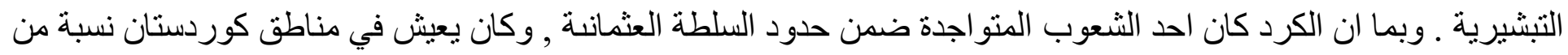

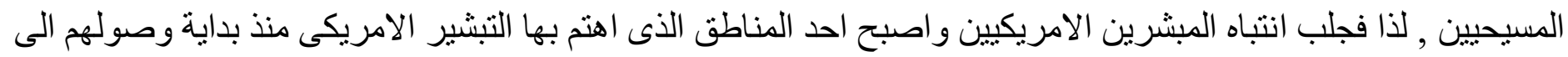

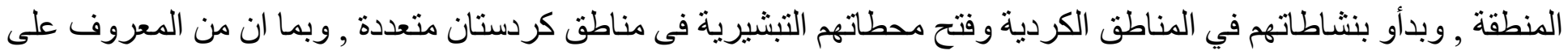

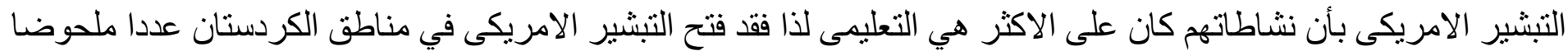

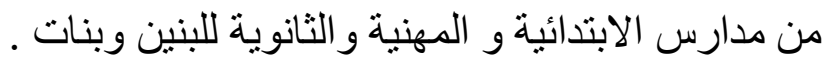

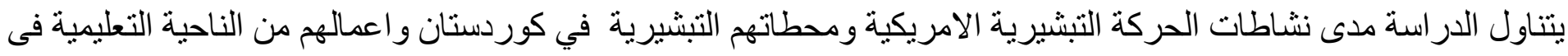

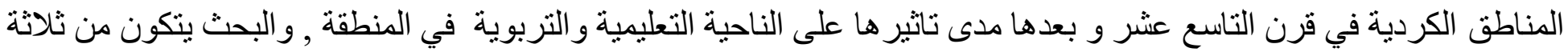

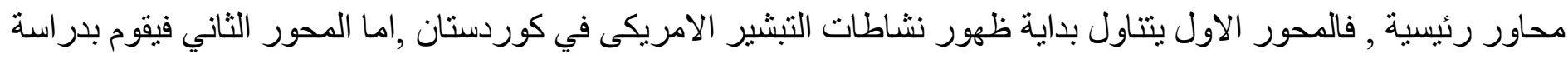

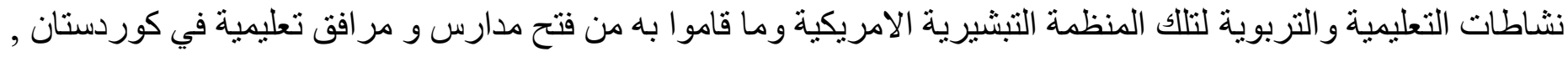

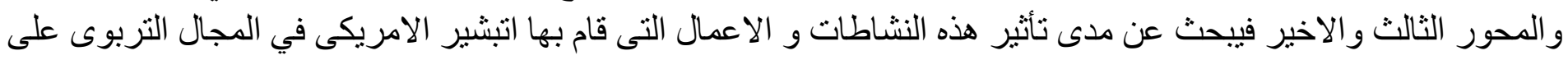

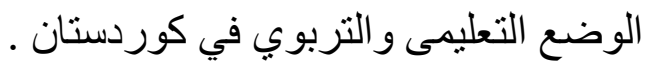

الكلمات اللاللة؛ مدرسة , التبشير الامريكى, كوردستان , التعليم. 


\section{سلورجاومكان:}

سالنامات نظار ات معارف عموميه,1317 , دار الخلافة العلمية , مطبعة عامرة .

Akalin, Berrin.( 2015),Ottoman-American Relations, Francis Hopkins Smith and Armenian Issue, Journal of International Education and Leadership Volume 5 Issue 1 Spring.

Anderson, Rufus. (1872), History of the Missionary of the American Board to the Oriental Churchs, Vol.1, Bostn.

Avarogullari,Muhammet and Yildiz, Ozgur,(2015),

Role of American protestant Missionariens Late Ottoman Empire Educational System,Turkish International Perodical for the Languages, Literature and History of Turkish ,V,10/9.

Dennis, James .(1893), Foreign mission after century, New York.

Dennis, James. (1903) ,Missions and social progress, Vol.(3),pub. Fleming H. Revel company Madison.

Dogan, Mehmet Ali .(2013),American Board of Commissioners for Foreign Missions (ABCFM)and Nominal Christians, Elias Riggs (1810 -1901),and American Missionary Activites in the Ottoman Empire. 
Erban,Cegri.(2000),Ottoman Official Attitudes Towards American Missonaries, International Confrence on 'the United States and the Middle East: Cultural Encounters, Yale University.

Fulya Damla Kentli,(2009), Foreign Schools in Turkey: Parents' Reasons to Choose, Ozean journal of social sciences.

Karabekmez, Meryem,(2012), The Role of Provincial Directors of Education in the Formation of Modern Ottoman Schooling ,1881-1908,(Master of Science in History) the Graduate School of Social Sciences, Istanbul Sehir University .

Kennedy, W. Judd.(2008),American Missionaries in Turkey and Northern Syria and the Development of Central Turkey and Aleppo Colleges, 1874-1967,College of William and Mary Publish.

Gokce، Feyyat.(2010),Minority and Foreign Schools on the Ottoman Education System.eintarnational journal of of educational research Volume: 1 Issue: 1- Summer.

Goodell,William.(1883),Forty Years in the TurkishEmpire ,NewYork.

Moritz, Wanger. (1856), travel in Persia, Georgia and Kurdistan, Vol.(3),Hurst and Blacket, London .

Ozutuk,Ayhan and Yildiz,Ozgur,(2013),Religious and Educational Activities of American Protestant Missionaries in Bursa,Cumhuriyrt International Journal of Education,V,2, No1. 
The One Hundredth Annual Report of the American Bord Commissioners for foreign missions ,(1910),Bostn.educational research ,V,1.

Thomas ,Laurie.(1853),Dr Grant and the Nestorian,Edinburge.

Umit, Devrim, (2014), The American Protestant Missionary Network in Ottoman Turkey,18761914,International,Journal of Humanities and Social ,V ,4,No,6,.

احمد، ابر اهيم خليل.( 1982)، تطور التعليم الوطنى فى العراق (1869-1932 ) .

الاسدى ، ناهدة حسين علي,الارساليات التبشيرية الامريكية في العراق و موقف الدولة العثمانية ,المجلة السياسية و الدولية .

اسماعيل، عامر بلو.( 2009)،التعليم التبشيرى الامريكي في الموصل منذ اواخر العهد العثماني حتى عام 1932,مجلة

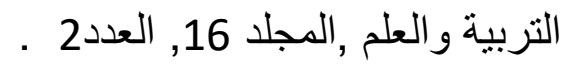

الامير ، ا.د. ليلى ياسين.( حزيران 2005),النشاط التعليمى للارسالية المريكية في البصرة 1912- 1958 , دراسات

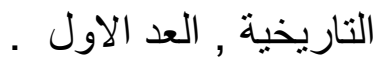

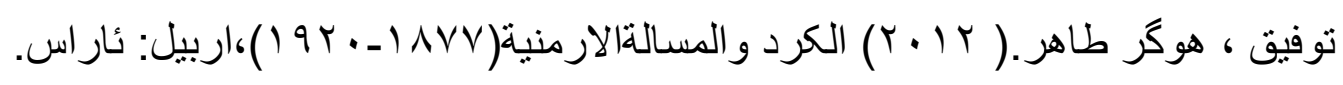

عباس ،محمد احمد.(2010),البعثات التبشيرية في كردستان في نصف الثاني من القرن التاسع عشر , رسالة ماجستير غير منشورة),كلية اداب, جامعة صلاح الدين.

عيسى، د. عبدالرزاق عبدالرزاق.( 2005 )التنصبر الامريكى في بلاد الثام 1834 -1914 ,القاهرة. 
غنيمة, حارث يوسف .(1998), البرونستانت و الانجيليون في العراق، مطبعة النانر المكتبي ، بغداد .

هاثثم ، د.سو ادي هاثم .(حزير ان 2006),النشاط التبشيري الامريكي في شمال غرب بلاد فارس 1833-1870 ,در اسات الاقليمية , السنة 3, العدد 5 .

هياجنة، ايمان عبدالرحمن وملكاوى ،حنان سليمان .( 2014) التبشير الفرنسي الكاتوليكي في و لاية الاناظول في القرن

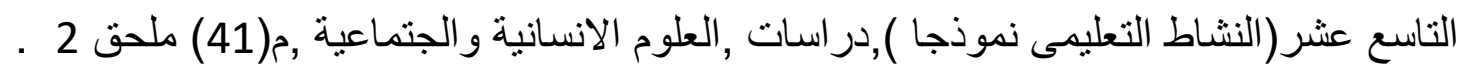

